\title{
Returns to Communication in Specialised and Diversified US Cities
}

Suzanne Kok 



\title{
Returns to Communication in Specialised and Diversified US Cities
}

\author{
Suzanne Kok ${ }^{1}$
}

\begin{abstract}
This paper documents and interprets the significance of communication for individual wages within cities with a diversified or specialised industrial structure. Diversified cities house firms which are optimizing their production process by learning from a wide variety of firms. Specialised cities house firms benefiting from the co-agglomeration of similar firms. We find substantial individual wage returns to the performance of communication job tasks in both specialised and diversified US cities in 2009. Communication seems to be less important for the production processes of firms in specialised cities as it is valued less in these cities than in diversified cities. The results are robust to a variety of specifications and other explanations, such as unobserved ability and variation in returns to communication across skill levels. Our results indicate that there is no one-type-fits-all advantage of city environments.
\end{abstract}

Keywords: Cities; Communication; Diversity; Specialisation

JEL Classification: J31; R19; D83

\section{Introduction}

A key factor in today's urban wealth is the means by which cities reduce costs of communication. Rapid progress in transport, information and communication technologies lowered the costs of production at distance. Still, in 2009 metropolitan areas were responsible for 85 percent of US employment, income and production. The significance of personal communication for innovation is a fundamental aspect of the current economic success of cities. The economic structure of cities varies; diversified cities focusing on producing ideas and specialised cities focusing on producing products successfully coexist in the US. Is communication equally important and valued within both city types?

Variation in the advantages of clustering of economic activity resulted in the existence of different economic city structures. Typically two types of cities coexist in the US: cities with a specialised industrial structure and cities with a diversified industrial structure (Duranton and Puga (2000)). Within specialised cities firms benefit from cost sharing, labour matching and learning from similar firms. The production costs are relatively low in these cities and the focus lies on producing products. A diversified environment with a wide variety of firms and ideas is more beneficial for innovation and producing ideas. The knowledge spillovers are more extensive in diversified cities but the production costs are higher. Especially for young firms and products the flows of ideas within diversified cities are key to success, while more mature firms flourish in specialised cities (Duranton and Puga (2001) and Desmet and Rossi-Hansberg (2009)). These variations in trade-offs between knowledge spillovers and production costs suggest that communication is less important within specialised cities. However, this suggestion does not reconcile with the assigned role of knowledge spillovers in the success of specialised clusters such as Silicon Valley.

In this paper we focus on the role of communication within the coexistence of diversified and specialised cities. We measure the individual returns to communication job tasks in a cross-

\footnotetext{
${ }^{1}$ University of Groningen and CPB Netherlands Bureau for Economic Policy Analysis, Van Stolkweg 14, 2585JR Den Haag, s.j.kok@cpb.nl.

I thank Steven Brakman, Harry Garretsen, Andrea Jaeger, Jasper de Jong, Bas ter Weel, two anonymous referees and seminar participants at the SOM conference and the Tinbergen Workshop for many insightful comments.
} 
section of both city types in the US. Workers, who communicate more in and outside the organisation, earn higher wages. The main contribution to regional science and policy is our finding that the importance of communication decreases with the specialisation level of cities.

First, a simple framework is set out to guide our empirical analyses. The framework captures an economy with perfect competition, free firm entry, full mobility of labour and spatial wage differences. The differences in wages across local labour markets are compensated with differences in productivity, labour ability and other local characteristics. In equilibrium both firms and workers are indifferent towards location. The productivity of a firm increases with the specialisation level of the city when the firm operates in the dominant industry of the city, hence the industry in which the city specialises. The productivity benefits of local communication decrease with the specialisation level of the city.

Second, we estimate the returns to communication job tasks for workers in the largest 168 US cities in 2009. Individual data from the Current Population Survey is combined with the job characteristics from the ONET Skill Survey. The performance of communication job tasks is defined by the work context and work activities information from the ONET Skill Survey. We start by estimating simple wage regressions in which we test the correlation between communication job tasks and individual wage, conditional on several individual and city characteristics. We find a positive relation between the number of communication job tasks a worker performs and his wage. Furthermore, our estimates show that this relation is present in both specialised and diversified cities but diminishes with the specialisation level of the city. The correlation between wage and communication is significantly stronger in diversified cities than in specialised cities.

Third, we control for differences in unobserved ability and perform IV-estimates. The occupational communication job tasks are instrumented with a language-skill proxy. Workers with weaker language-skills are assumed to be less likely to perform communication job tasks. The language-skill proxy measures the share of workers in an occupation who did not grow up in an English-speaking household. Several tests prove that the language-skill proxy does not measure the wage impact of cultural differences. Following Ciccone and Hall (1996) historical population (1930) is used as an instrument for current city size or the extent to which the industrial structure is either specialised or diversified. The IV-estimates correspond to the OLS-estimates. A one standard deviation increase in the importance of communication, increases wages by $18 \%$ of a standard deviation. However, in cities with a specialised sectoral structure, these returns are about $16 \%$ of a standard deviation. The returns are somewhat higher in large cities: about $21 \%$ of a standard deviation. The returns to communication do not vary with the diversity level of the city. The variation in returns to communication over city types explains part of the lower wages in specialised cities and part of the higher wages in larger cities.

Lastly, we carry out several robustness checks and analyse alternative specifications. First, we test the sensitivity of the measure of communication and measure the returns to the relative importance of communication, non-routine interactive tasks as in Autor e.a. (2003) and people skills as in Bacolod e.a. (2009). Next, we perform an additional test on the effect of unobserved ability and allow the returns to communication to vary across skill level (Glaeser and Mare (2001)). The results are robust to all these specifications. Moreover, the results hold for both industrial sectors and service sectors.

Our work is based on a small theoretical literature explaining the coexistence of diversified and specialised cities. Duranton and Puga (2001) and Desmet and Rossi-Hansberg (2009) set up a dynamic general-equilibrium model which explain the co-existence of the two city types within the life-cycle of respectively firms and industries. Glaeser and Ponzetto (2007), Gaspar and Glaeser (1998) and loannides e.a. (2008) model two rival spatial effects of technological progress. All these papers underline their theory with empirical analyses. Furthermore, Harrison e.a. (1996), Kelley and Helper (1999) and Feldman and Audretsch (1999) document the contributions of sectoral diversity towards new production processes and new products. 
A very broad and extensive literature indicates the (non random) coexistence of diversified and specialised cities (e.g. Duranton and Puga (2000) and Ellison and Glaeser (1999)) and the relative advantages at the city level (see Glaeser and Gottlieb (2009) for an overview). The importance of communication in the current wealth of cities relates to empirical contributions of (among others) Jaffe e.a. (1993), Rauch (1993), Charlot and Duranton (2004), Bacolod e.a. (2009) and Florida e.a. (2012). Our work adds to these contributions by focussing on the variation in returns to communication between different city types. Therefore, we focus on the suggested microfoundations of the coexistence of these two city types as in Duranton and Puga (2001).

The rest of the paper is structured as follows. The next section discusses a simple framework underlying our ideas and section 3 sets out the estimation strategy of this framework. Section 4 describes the construction of the database and some descriptive statistics. Section 5 presents the OLS-estimates and section 6 the IV-estimates. In section 7 several other specifications are tested for robustness. Section 8 concludes.

\section{Spatial wage differences and communication}

Before we present the estimates of the returns to communication we set out a framework which captures the underlying mechanism. Our framework explains the existence of spatial wage differences and the role of communication. It relies on the assumption that in equilibrium wage differences are possible while workers and firms should be indifferent to location. Local markets (i) are characterised by (both observed and unobserved) ability, productivity level, price level, and industrial structure (specialisation level).

\subsection{General Setting}

We consider an economy with perfect competition, free firm entry and full mobility of labour. Firms either focus on mass-products or on new and developing products. Firm's output is a function of productivity $(A)$, number of workers $(L)$ and city characteristics $(C): Y=f(A, L, C)$. These factors are mutually dependent. The productivity of a firm, for example, depends on its workers and its location and varies between mass-production and developing production (see Duranton and Puga (2001) and Desmet and Rossi-Hansberg (2009)). The free entry assumption implies that firms obtain zero profits. As often noted in the literature, large spatial wage differences exist (e.g. Glaeser and Mare (2001)). The spatial wage differences are compensated by spatial variation in the input factors productivity, labour and city characteristics. In equilibrium workers and firms are indifferent regarding location $i$. The spatial variation in $A$ and $C$ explains why not all workers move to the high wage cities and not all firms move away from these cities.

\subsection{Spatial distribution of firms}

Following the theoretical work of Duranton and Puga, firms locate in a less specialised (or diversified) city during the learning stage and development of their ideal production process. In these 'nursery' cities firms learn from the ideas and knowledge of a broad variety of firms. Human capital externalities are crucial for the productivity and innovation of new products as the crossfertilisation of ideas and knowledge stimulates the generation of new ideas (Lucas (1988), Duranton and Puga (2001) and Desmet and Rossi-Hansberg (2009)). When firms find their optimal production process and move to mass-production they relocate to more specialised cities. Specialised cities house a co-agglomeration of similar firms which enables firms to share, match and learn from their direct competitors.

\subsection{Productivity}

The ability of the local work force varies over space (Combes e.a. (2008)). All firms benefit from a productive labour force $\left(\varphi_{i}\right)$. The determinants of local productivity vary with the local specialisation level $\left(\rho_{i}\right)$. Firms who focus on mass-production and locate in specialised cities benefit from sharing 
facilities, matching labour and knowledge spillovers from similar firms. If the firm operates in the dominant local industry, productivity rises with the specialisation level $\left(M^{\rho_{i}}\right) .{ }^{2} \mathrm{~A}$ mature firm in the textile industry benefits from the co-location of textile industry and a high local specialisation level in this industry.

As indicated, both firms in specialised and diversified cities benefit from learning and communication with other firms. The cross-fertilisation of ideas is more likely to happen when people meet face to face. Not only is face to face contact a very efficient communication technology, it also helps solving incentive problems and more importantly facilitates learning and human capital externalities (Storper and Venables (2004)). ${ }^{3}$ The amount of local knowledge spillovers and communication depends on the allocation of labour between core work activities and communication tasks. Core work activities are the job tasks of the occupation of the worker. Communication tasks contain the communication with other workers (in or outside the firm) about work activities. $\theta$ is the fraction of labour spend on communication tasks. The firm allocates labour optimally between work activities and communication tasks given local characteristics. However, learning and communication are more crucial for firms in less specialised cities which still optimize their production process by learning from others (Duranton and Puga (2001) and Desmet and RossiHansberg (2009)).

To sum up, the productivity of a firm $(A)$ depends on whether the firm operates in the local dominant industry $(M)$, the specialisation level of the local industry $\left(\rho_{i}\right)$, the amount of local communication $(\theta L)$ and the ability or productivity of the local work force $\left(\varphi_{i}\right)$. Firms which operate in the local industry experience a productivity which increases with the local specialisation level. The productivity benefits of local communication, on the other hand, decrease with the specialisation level of the city.

where $0<\rho_{i}<1$ and $E=d \theta L$

$$
A=M^{\rho_{i}} E^{\left(1-\rho_{i}\right)} \varphi_{i}
$$

Labour input to produce output only includes the fraction of labour spend on work activities $((1-\theta) L)$. Output is produced with labour spend on work activities (which decreases with the fraction spend on communication) at a productivity level that increases with the fraction spend on communication:

$$
Y=A((1-\theta) L)
$$

\subsection{Optimal allocation of labour}

Output is only produced with work activities while wages and rents are paid for both communication tasks and work activities $(L)$. Local wages $\left(W_{i}\right)$ and rents $\left(R_{i}\right)$ are given. Congestion costs cause the local rents to rise with the size of the local market.

$$
\pi=A(1-\theta) L-W_{i} L-R_{i}
$$

There is a trade-off between spending labour on communication and increasing productivity and spending labour on work activities and increasing production input. This trade-off varies with the local level of specialisation $\left(\rho_{i}\right)$. Firms maximize profits $(\pi)$, given the local dominant industry, specialisation level and rents, and optimally allocate labour between communication tasks and work activities. They optimize the following equation:

\footnotetext{
${ }^{2} \mathrm{M}$ is the productivity effect of operating in the local dominant industry. This effect increases with the specialisation level of the city.

${ }^{3}$ This explains why human capital spillovers and learning are bound by distance (Jaffe e.a. (1993) and Jacobs (1969)).
} 


$$
\pi=M^{\rho_{i}}(d \theta L)^{\left(1-\rho_{i}\right)} \varphi_{i}(1-\theta) L-W_{i} L-R_{i}
$$

Optimizing equation (4) leads to the following optimal allocation of labour between core activities $(1-\theta)$ and communication about core activities $(\theta)$, given the local specialisation level $\rho_{i}$ :

$$
(1-\theta)=\frac{\theta}{1-\rho_{i}}
$$

Substituting the optimal allocation of labour into equation (3) it follows that:

$$
\pi=b \varphi_{i} M^{\rho_{i}}(\theta L)^{\left(2-\rho_{i}\right)}-W_{i} L-R_{i}
$$

where $b=\frac{d^{1-\rho_{i}}}{1-\rho_{i}}$

\subsection{Individual wages}

Firm entry is free which implies zero profits. This leads to the following total labour costs:

$$
W_{i} L=b \varphi_{i} M^{\rho_{i}}(\theta L)^{\left(2-\rho_{i}\right)}-R_{i}
$$

We assume that individual wages correspond to individual ability. Setting $L$ to 1 , individual worker wage is then:

$$
W_{k}=b \varphi_{k} M^{\rho_{i}}\left(\theta_{k}\right)^{\left(2-\rho_{i}\right)}-R_{i}
$$

The individual wage is determined by a constant, the ability of the worker $\left(\varphi_{k}\right)$, the level of local specialisation $\left(\rho_{i}\right)$, whether the worker works in the dominant industry $(M)$, the fraction of labour which the worker spends on communication $\left(\theta_{k}\right)$, and the average local rent costs $\left(R_{i}\right)$. If the worker works in the dominant local industry, his wage rises with the local industrial specialisation of the relevant industry. However, the wage benefits of communication decrease with the local level of specialisation:

$$
\begin{gathered}
\frac{\partial W_{k}}{\partial \theta_{k}}>0 \\
\frac{\partial W_{k}^{2}}{\partial \theta_{k} \rho_{k}}<0
\end{gathered}
$$




\section{Empirical strategy}

\subsection{Reduced form}

We bring equation (8) to the data and estimate the reduced form for worker $k$ in city $i$.

$\ln w_{k i}=\alpha_{1}+\alpha_{2} \hat{\varphi}_{k}+\alpha_{3} \widehat{M}_{k}+\beta_{1} \hat{\theta}_{k}+\beta_{2} \hat{\rho}_{i}+\beta_{3} \hat{R}_{i}+\gamma_{1}\left(\hat{\theta}_{k} \cdot \hat{\rho}_{i}\right)+\gamma_{2}\left(\widehat{M}_{k} \cdot \hat{\rho}_{i}\right)+\varepsilon_{k i}$

where $w_{k i}$ is the hourly wage earnings of individual $k$, in city (Metropolitan Statistical Area) $i$. Individual ability is estimated by $\hat{\varphi}_{k}$ : a set of standard, demographical controls (age, age squared, gender, race and marital status), a set of occupational dummies and a set of education dummies of the highest grade completed. $\widehat{M}_{k}$ represents the productivity effect of mass-production and indicates whether individual $\mathrm{k}$ works in the dominant industry city $i$ or not. Indicator $\hat{\theta}_{k}$ denotes the estimate of the performance of communication tasks by worker $k .{ }^{4}$ The local level of specialisation is estimated with the Regional Specialisation Index $(R S I)$. The $R S I$ calculates the maximum overrepresentation (subject to national share) of an industry in the city. $\hat{\rho}_{i}=\max _{i} \log E_{i j}-\log E_{j}$ in which $E_{i j}$ represents the employment share of industry $j$ in city $i$ and $E_{j}$ the employment share of industry $j$ in national employment. We allow the returns to communication to vary with the local specialisation level $\left(\gamma_{1}\left(\hat{\theta}_{k} \cdot \hat{\rho}_{i}\right)\right)$. The returns to working in the local dominant industry vary with the local level of specialisation as well $\left(\gamma_{2}\left(\widehat{M}_{k} \cdot \hat{\rho}_{i}\right)\right)$. Lastly, $\hat{R}_{i}$ indicates the average rent costs in city $i$.

\subsection{Measurement}

The estimation of this empirical model requires a number of assumptions. First, the indicator for communication tasks $\left(\hat{\theta}_{k}\right)$ and its interaction with local industrial specialisation $\left(\hat{\theta}_{k} \cdot \hat{\rho}_{i}\right)$ are measured at aggregated levels and do not vary by worker. The dependent variable $\left(w_{k i}\right)$ is however measured at the worker level. This leads to underestimation of the standard errors as indicated by Moulton (1990). To avoid this issue, we cluster standard errors at the occupational level.

Second, endogeneity issues may bias our OLS-estimates. The ability of individuals is estimated and not fully observed. The measurement error $\varepsilon_{k i}$ includes ability characteristics $\left(A_{k}\right)$ such as talent and work discipline and some measurement error at the individual and city level $\left(\mu_{k i}\right)$ : $\varepsilon_{k i}=A_{k}+\mu_{k i}$. When $A_{k}$ correlates with the local specialisation level $\rho_{i}$ or city size $R_{i}$, we cannot isolate the effect of these indicators on wages and the estimates become biased. To deal with endogeneity, section 6 shows the results of instrumenting communication.

Third, specialisation and diversity are not opposite measures. The RSI measures the overrepresentation of an industry in city $i$ while the local diversity level reflects the mixture of industries within the city. Thus, the regional diversity index $(R D I)$ captures all industries in the city while $R S I$ only includes information on the dominant industry. ${ }^{5}$ We experiment with including both $R S I$ and RDI.

Fourth, specialised cities tend to be smaller than diversified cities (e.g. Duranton and Puga (2000)). ${ }^{6}$ Hence, $\hat{\rho}_{i}$ correlates strongly with city size. The correlation between the size and the specialisation (and diversity) is too strong to include both in the regressions. Therefore, we attempt additional estimates with only city size and a cross-term of city size with communication.

Lastly, work activities might also involve communication. Especially low skilled service occupations often involve several communication tasks such as waiting tables. We aim however to measure the returns to communication about job activities, for example a worker who informs his manager about the results of his analyses. To distinguish between these two forms of

\footnotetext{
${ }^{4}$ As explained in the next section, data limit us to measure communication at the occupational level.

${ }^{5} R D I$ is defined as $R D I_{i}=\frac{1}{\sum_{j} E_{i j} / E_{j}}$ where $E_{i j}$ represents employment in industry $j$ in city $i$ and $E_{j}$ national employment in industry $j$.

${ }^{6}$ In our dataset diversified cities are as well larger than specialised cities, which is discussed in Section 4.2.
} 
communication we include information about communication work activities as well. Communication work activities are defined as the ONET work activity 'performing for or working directly with the public' with the description: 'Performing for people or dealing directly with the public. This includes serving customers in restaurants and stores, and receiving clients or guests'.

\section{Data}

\subsection{Database construction}

We use individual wage data for 2009 provided by the Current Population Survey (CPS). For each individual it contains information on personal characteristics (education level, age, marital status etc), occupation, industry, wage and location. Occupations are converted to a time-consistent scheme of 326 occupations (as in Autor and Dorn (2010)). Our sample consists of working individuals living in Metropolitan Statistical Areas (MSAs) in 2009, aged between 16 and 65, working outside the agricultural sector. We exclude all self-employed workers. This results in a sample of 83,078 individuals.

Wages are measured by hour. Following Lemieux (2006), outliers are removed by trimming very small (hourly wage below $\$ 1$ ) and very large values (hourly wage above \$101) of wages. Hourly wages above $\$ 101$ are top coded within the CPS and are therefore replaced with the 1.4 top coded value. For missing wage values we apply a no-imputation approach. The no-imputation method excludes the wages of missing cases but counts them when calculating occupational sizes (Mouw and Kallenberg (2010)).

Communication job tasks and work activities are collected from the ONET Skill Survey. The ONET data characterizes the workers abilities, interest, knowledge, skills, work activities, work context and work values, by occupation. Three types of work activities and three work context items are included as communication job tasks. They measure the importance of:

- Establishing and maintaining interpersonal relationships (label "relations")

- Communicating with persons outside organization (label "external communication")

- Communicating with supervisors, peers, or subordinates (label "internal communication")

- Face-to-Face discussions (label "Face-to-Face")

- Work with work group or team (label "teamwork")

- Contact with others (label "contact")

Table 1 lists the ONET definition of these communication job tasks. We normalise the scores of these variables (mean 0 and standard deviation 1 ) to equalise scaling. ${ }^{7}$ The communication job task scores of the occupations are matched to the occupations in the CPS database. A Communication-Index is estimated by using principal component analyses:

$$
Y_{i}=\beta_{i} \text { Communication }+\varepsilon_{i}
$$

$Y$ is the constructed index based on the input of the 6 communication tasks represented by $i$. The estimates are presented in Appendix $C$, together with the correlations between the communication tasks. The principal component loadings $\left(\beta_{i}\right)$ could be viewed as weights and are rather equal for all communication tasks in the first component. The first component explains about 0.60 percent of the total variation in the 6 tasks. The first component explains a substantial larger variation than the other components. Therefore, the first component is defined as the Communication-Index.

Employment figures are gathered from the Local Area Unemployment Statistics from the Bureau of Labor Statistics Additional. The employment figures include information on the total employment in the city and the employment by industry (which is used for the construction of the

\footnotetext{
${ }^{7}$ Appendix A provides insight in the original scaling of the variables.
} 
Table 1: Communication Job Tasks

\begin{tabular}{|c|c|c|}
\hline & Definition by ONET & $\begin{array}{r}\text { Correlation } \\
\text { with wage }\end{array}$ \\
\hline Relations & $\begin{array}{l}\text { Developing constructive and cooperative working relationships with } \\
\text { others, and maintaining them over time. }\end{array}$ & $0.34^{* * *}$ \\
\hline $\begin{array}{l}\text { External } \\
\text { communication }\end{array}$ & $\begin{array}{l}\text { Communicating with people outside the organization, representing } \\
\text { the organization to customers, the public, government, and other } \\
\text { external sources. } \\
\text { This information can be exchanged in person, in writing, or by } \\
\text { telephone or e-mail. }\end{array}$ & $0.39 * * *$ \\
\hline $\begin{array}{l}\text { Internal } \\
\text { communication }\end{array}$ & $\begin{array}{l}\text { Providing information to supervisors, co-workers, and subordinates } \\
\text { by telephone, } \\
\text { in written form, e-mail, or in person. }\end{array}$ & $0.35^{* * *}$ \\
\hline Face-to-face & $\begin{array}{l}\text { How often do you have to have face-to-face discussions with } \\
\text { individuals or teams in this job? }\end{array}$ & $0.27^{* * *}$ \\
\hline Teamwork & $\begin{array}{l}\text { How important is it to work with others in a group or team in this } \\
\text { job? }\end{array}$ & $0.14 * * *$ \\
\hline Contact & $\begin{array}{l}\text { How much does this job require the worker to be in contact with } \\
\text { others (face-to-face, by telephone, or otherwise) in order to } \\
\text { perform it? }\end{array}$ & $0.05^{* * *}$ \\
\hline $\begin{array}{l}\text { Communication- } \\
\text { Index }\end{array}$ & Principal-component index of the above six tasks & $0.35 * * *$ \\
\hline
\end{tabular}

local specialisation level). Lastly, additional city data, such as average rents, are collected from the Census Decennial Database.

Appendix A describes the data sources, Appendix B describes the used classifications and Appendix $C$ includes a list of all the used variables, their measurements and source.

\subsection{Descriptive statistics}

Before we proceed to present a set of estimates, we first discuss the descriptive statistics. Table 2 provides an overview of the characteristics of our entire sample of 83,078 individuals. The average worker earns 22 US dollars per hour, is 40 years old and works in a city of almost 1.3 million employees. One out of two workers is female. Individuals who perform more communication job tasks earn higher wages, live more often in diversified cities, are more often high educated and female.

The last column of table 2 shows the correlations between the performance of the six communication job tasks and individual wages. All the correlations are positive and significant. The establishment of relations, communication outside the organisation and communication with workers inside the organisation show the strongest correlations with individual wages. The measure for contact in general only weakly correlates with wages. Cities which house many communication intensive occupations also obtain high average wages (correlation of 0.71 , significant at the 1 percent level, see figure 1). The relation between local wages and local communication, as predicted in equation (6) does hardly show any outliers. Ann Arbor has the most communication intensive labour market and is the sixth city on the wage ranking. Canton-Massillon has the least communication intensive labour market and only 17 of the 168 cities have a lower average wage than Canton-Massilon.

Equation (1) suggests that cities with a lower specialisation level benefit more from the performance of communication tasks. Indeed, workers in diversified cities perform on average more communication tasks, while workers in specialised cities perform less communication tasks (see figure 2). Given a certain level of diversity or specialisation, the variation in communication is however large between cities. On average, wages are also higher in diversified cities and lower in specialised cities. Appendix $C$ presents a correlation matrix of all variables. 
Table 2: Summary statistics

\begin{tabular}{|c|c|c|c|c|c|}
\hline & Mean & $\begin{array}{l}\text { Standard } \\
\text { deviation }\end{array}$ & Minimum & Maximum & $\begin{array}{l}\text { Correlation } \\
\text { with } \\
\text { Communication } \\
\text { Index }\end{array}$ \\
\hline Hourly wage & 21.9 & 16.26 & 2.49 & 230.6 & $0.35^{* * *}$ \\
\hline $\begin{array}{l}\text { Communication } \\
\text { Index }\end{array}$ & 0.43 & 0.89 & -3.11 & 2.46 & $1.00^{* * *}$ \\
\hline Specialisation-city & 0.00 & 1.00 & -1.46 & 3.74 & $-0.05^{* * *}$ \\
\hline Diversity-city & 0.00 & 1.00 & -2.17 & 1.69 & $0.02^{* * *}$ \\
\hline Employment-city & $1,311,017$ & $1,136,008$ & 60,580 & $4,328,589$ & $0.01^{* * *}$ \\
\hline Dominant industry & 0.01 & 0.11 & 0.00 & 1.00 & $-0.03 * * *$ \\
\hline $\begin{array}{l}\text { High-school drop- } \\
\text { out }\end{array}$ & 0.08 & 0.27 & 0.00 & 1.00 & $-0.31^{* * *}$ \\
\hline High-school & 0.26 & 0.44 & 0.00 & 1.00 & $-0.28^{* * *}$ \\
\hline Some college & 0.29 & 0.45 & 0.00 & 1.00 & $-0.02^{* * *}$ \\
\hline College graduate & 0.37 & 0.48 & 0.00 & 1.00 & $0.44^{* * *}$ \\
\hline $\begin{array}{l}\text { Communication } \\
\text { job activities }\end{array}$ & 2.55 & 0.98 & 1.00 & 4.83 & $0.33^{* * *}$ \\
\hline Non-white & 0.21 & 0.41 & 0.00 & 1.00 & $-0.04 * * *$ \\
\hline Non-married & 0.45 & 0.50 & 0.00 & 1.00 & $-0.11^{* * *}$ \\
\hline Age & 4.00 & 12.44 & 16.00 & 64.00 & $0.10^{* * *}$ \\
\hline Female & 0.52 & 0.50 & 0.00 & 1.00 & $0.14^{* * *}$ \\
\hline
\end{tabular}

Note: source Current Population Survey 2009, n=81262

Figure 1: Wages and communication in cities

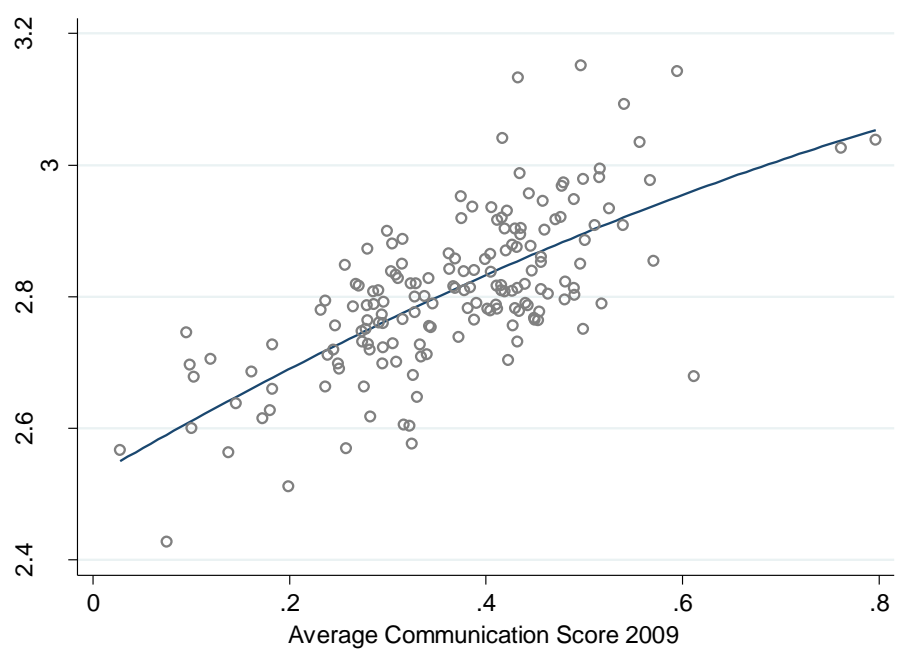

Note: source Current Population Survey 2009. City level data, $n=168$. The correlation is $0.71(0.00)$ and significant at the $1 \%$ level. Communication is measured as the average score on the Communication-Index as defined in Section 4 . Wage is measured as average hourly wage 2009 in logs. 


\section{Figure 2: Communication in specialised and diversified cities}
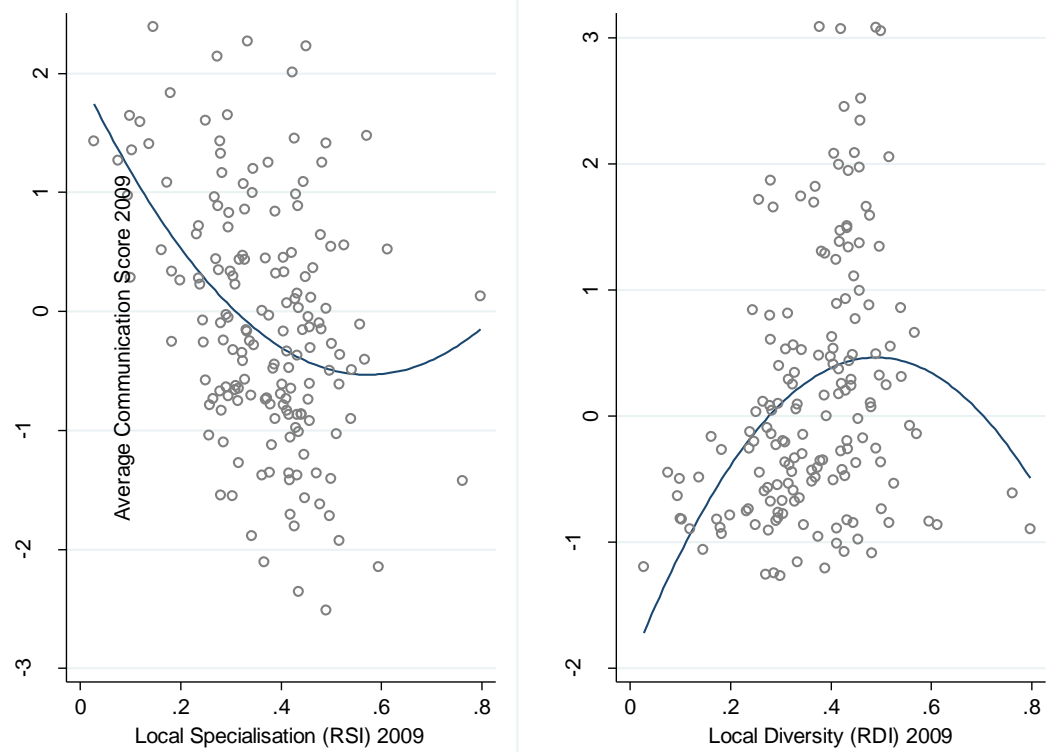

Note: source Current Population Survey 2009. City level data, $n=168$. The correlations are respectively $-0.40(0.00)$ and $0.33(0.00)$ and significant at the $1 \%$ level. $R S I$ and $R D I$ are measured as described in Section 3 . Communication is measured as the average score on the Communication-Index as defined in Section 4.

\section{Figure 3: Wages in specialised and diversified cities}
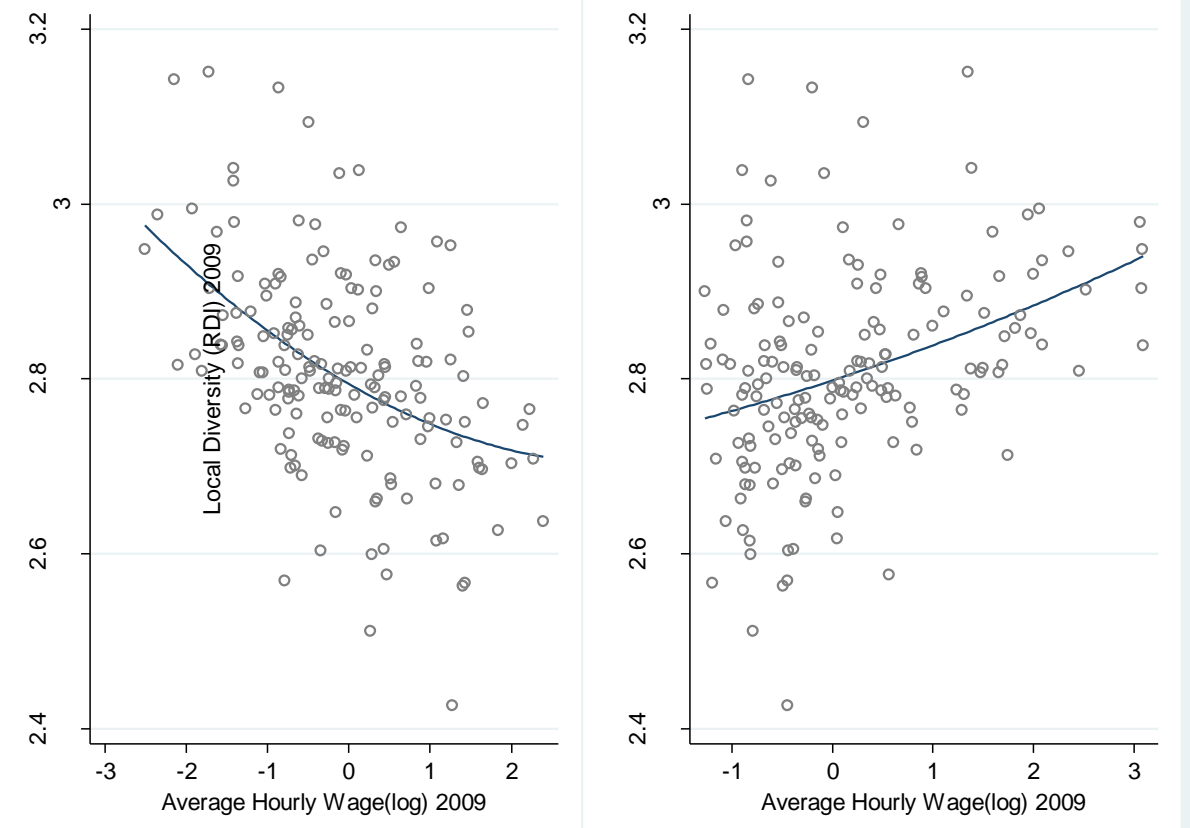

Note: source Current Population Survey 2009. City level data, $n=168$. The correlations are respectively $-0.46(0.00)$ and $0.36(0.00)$ and significant at the $1 \%$ level. $R S I$ and $R D I$ are measured as described in Section 3. Wage is measured as average hourly wage 2009 in logs. 


\section{OLS-estimates}

Before we address causality, we present a set of OLS-estimates to show the relationship between wage and communication in a more rigorous way. Column 1 in Table 3 presents the estimates of a straightforward wage regression. We find the usual returns to education (e.g. as in Rauch (1993) and Bacolod e.a. (2009)). Both industrial specialisation and diversity correlate negatively with individual wages. The positive correlation between local diversity and individual wage (as found in section 4.2) turns negative when we control for demographic and educational factors. Workers who work in the dominant local industry ( $M$ in equation (11)) earn substantially more than workers who do not work in the dominant industry. This effect increases with the specialisation level of the city. Notable is the positive impact of rents on wages which indicates the cities' role of centres for consumption (Glaeser e.a. (2001)). All the covariates, such as age and gender, obtain the expected sign and size.

Next, we test whether the correlations between wages and communication vary with the industrial specialisation and diversity level of the city. Column (2) includes a cross-term between communication and the local specialisation level (all variables are standardised to ease comparison). The coefficient of the cross-term is negative and significant: the correlation between wage and performed communication tasks is weaker in specialised cities. The linear impact of communication remains positive and significant, while the size of the coefficient of local specialisation decreases. Column (3) performs the same regression but includes a cross-term between communication and sector diversity instead of sector specialisation. The coefficient of the cross-term is positive and significant. Both in specialised and in diversified cities workers in communication intensive jobs earn more, but this relation is stronger in diversified cities and weaker in specialised cities.

Lastly, we allow the relation between wages and communication to vary across city size. Diversified cities are on average larger than specialised cities. Column (5) presents the baseline results including city size instead of industrial structure and column (6) presents the results including the cross-term as well. The correlations between wage and performed communication tasks are stronger in larger cities. Workers in larger cities who perform communication tasks earn more than workers in small cities with the same task package. The positive coefficient of the cross-term between city size and communication outweighs the negative linear coefficient for communication. Similar to the theory of section 2 , individual wages increase with the ability of the worker, the communication of the worker when the local industry is not so specialised and the specialisation level when the worker works in the dominant industry. The OLS-estimates suggest that one standard deviation more communication job tasks increases wages with about $16 \%$ of a standard deviation. In specialised cities this is $13 \%$ of a standard deviation, in diversified cities $18 \%$ of a standard deviation and $20 \%$ in large cities.

\section{IV-estimates}

The main issue with OLS wage estimates is a possible omitted ability bias. Equation (1) distinguishes between an ability and a productivity effect. This distinction is hampered if workers in highly productive cities or jobs are simply 'better' in an unobserved way. Ability characteristics such as talent, work discipline and ambition are unobserved in our analyses. For instance, relatively talented workers might be attracted to certain cities. Diversified cities tend to be larger and house more amenities than the smaller, specialised cities. Talented workers could value these amenities more than less talented workers. Talent of workers is however not measured. In OLS-estimates the higher wages within these cities are assigned to higher local productivity of these cities while they might simply reflect higher (unobserved) ability levels. The same feature might bias the impact of communication on wage. It could be the case that communication intensive jobs offer more carrier opportunities in the long run. Workers with a relatively high ambition are more likely to sort into these jobs. In the OLS-estimates, the high wages of these jobs are related to the communication intensity while the impact of worker ambition is unobserved. Combes e.a. (2009) refer to this issue as the 'endogenous quality of labour' problem. 
Table 3: Returns to communication, specialised and diversified cities (OLS)

\begin{tabular}{|c|c|c|c|c|c|c|}
\hline & \multicolumn{6}{|c|}{ Dependent: individual wage (log) } \\
\hline & (1) & $(2)$ & $(3)$ & (4) & $(5)$ & $(6)$ \\
\hline \multirow[t]{2}{*}{ Communication } & & $0.098^{* * *}$ & $0.099 * * *$ & $0.098^{* * *}$ & & $0.098^{* * *}$ \\
\hline & & [0.019] & [0.019] & [0.019] & & [0.019] \\
\hline \multirow[t]{2}{*}{$\mathrm{COM}^{*}$ specialisation } & & & $-0.019 * * *$ & & & \\
\hline & & & [0.004] & & & \\
\hline \multirow[t]{2}{*}{$\mathrm{COM}^{*}$ diversity } & & & & $0.010^{* * *}$ & & \\
\hline & & & & {$[0.003]$} & & \\
\hline \multirow[t]{2}{*}{ COM*size } & & & & & & $0.023^{* * *}$ \\
\hline & & & & & & [0.004] \\
\hline \multirow[t]{2}{*}{ Specialisation } & $-0.038 * * *$ & $-0.038 * * *$ & $-0.030 * * *$ & $-0.038 * * *$ & & \\
\hline & [0.004] & [0.004] & [0.004] & [0.004] & & \\
\hline \multirow[t]{2}{*}{ Diversity } & $-0.009 * *$ & $-0.009 * * *$ & $-0.009 * *$ & $-0.014 * * *$ & & \\
\hline & {$[0.004]$} & [0.004] & {$[0.003]$} & [0.004] & & \\
\hline \multirow[t]{2}{*}{ Size } & & & & & $0.043^{* * *}$ & $0.035^{* * *}$ \\
\hline & & & & & {$[0.004]$} & [0.003] \\
\hline \multirow[t]{2}{*}{ Dominant industry } & $0.105^{* * *}$ & $0.118^{* * *}$ & $0.115^{* * *}$ & $0.119 * * *$ & $0.107 * * *$ & $0.120^{* * *}$ \\
\hline & {$[0.026]$} & {$[0.023]$} & {$[0.023]$} & {$[0.023]$} & {$[0.026]$} & {$[0.020]$} \\
\hline \multirow[t]{2}{*}{ DOM*specialisation } & $0.066^{* * *}$ & $0.065^{* * *}$ & $0.057^{* * *}$ & $0.060 * * *$ & $0.047^{* * *}$ & $0.039^{* *}$ \\
\hline & [0.018] & [0.018] & [0.017] & [0.017] & [0.017] & {$[0.017]$} \\
\hline \multirow[t]{2}{*}{ Drop-out } & $-0.204 * * *$ & $-0.185^{* * *}$ & $-0.183 * * *$ & $-0.185^{* * *}$ & $-0.204 * * *$ & $-0.181^{* * *}$ \\
\hline & [0.013] & [0.014] & [0.014] & [0.014] & [0.014] & [0.014] \\
\hline \multirow[t]{2}{*}{ College } & $0.080 * * *$ & $0.069 * * *$ & $0.069 * * *$ & $0.069 * * *$ & $0.080^{* * *}$ & $0.070 * * *$ \\
\hline & [0.008] & [0.008] & {$[0.008]$} & [0.008] & [0.008] & [0.008] \\
\hline \multirow[t]{2}{*}{ College grad } & $0.363^{* * *}$ & $0.348^{* * *}$ & $0.347 * * *$ & $0.348 * * *$ & $0.373^{* * *}$ & $0.357^{* * *}$ \\
\hline & {$[0.021]$} & {$[0.020]$} & {$[0.020]$} & {$[0.020]$} & {$[0.021]$} & {$[0.020]$} \\
\hline \multirow[t]{2}{*}{ Rent } & $0.046^{* * *}$ & $0.047^{* * *}$ & $0.047^{* * *}$ & $0.047^{* * *}$ & & \\
\hline & [0.003] & [0.003] & [0.003] & [0.003] & & \\
\hline \multirow[t]{2}{*}{ Communication job } & -0.018 & $-0.041 * * *$ & $-0.041 * * *$ & $-0.041 * * *$ & -0.018 & $-0.041^{* * *}$ \\
\hline & {$[0.015]$} & [0.013] & [0.013] & [0.013] & {$[0.015]$} & [0.013] \\
\hline \multirow[t]{2}{*}{ Non-white } & $-0.085^{* * *}$ & $-0.082 * * *$ & $-0.082^{* * *}$ & $-0.082^{* * *}$ & $-0.062^{* * *}$ & $-0.061 * * *$ \\
\hline & [0.008] & [0.007] & {$[0.007]$} & [0.007] & {$[0.007]$} & {$[0.007]$} \\
\hline \multirow[t]{2}{*}{ Non-married } & $-0.056 * * *$ & $-0.055^{* * *}$ & $-0.056 * * *$ & $-0.055^{* * *}$ & $-0.055^{* * *}$ & $-0.055 * * *$ \\
\hline & [0.007] & [0.006] & {$[0.006]$} & {$[0.006]$} & [0.007] & [0.006] \\
\hline \multirow[t]{2}{*}{ Age } & $0.049 * * *$ & $0.048^{* * *}$ & $0.049 * * *$ & $0.048^{* * *}$ & $0.050 * * *$ & $0.049 * * *$ \\
\hline & [0.003] & [0.003] & {$[0.003]$} & {$[0.003]$} & [0.003] & [0.003] \\
\hline \multirow[t]{2}{*}{ Age square } & $-0.000 * * *$ & $-0.000 * * *$ & $-0.000 * * *$ & $-0.000 * * *$ & $-0.000 * * *$ & $-0.000 * * *$ \\
\hline & {$[0.000]$} & {$[0.000]$} & {$[0.000]$} & {$[0.000]$} & {$[0.000]$} & [0.000] \\
\hline \multirow[t]{2}{*}{ Female } & $-0.184 * * *$ & $-0.183^{* * *}$ & $-0.183^{* * *}$ & $-0.183^{* * *}$ & $-0.185^{* * *}$ & $-0.184^{* * *}$ \\
\hline & [0.014] & [0.013] & [0.013] & [0.013] & [0.014] & [0.013] \\
\hline Occupation dummies & YES*** & YES ${ }^{* * *}$ & YES*** & YES*** & YES*** & YES*** \\
\hline Observations & 82705 & 82705 & 82705 & 82705 & 81262 & 81262 \\
\hline R-squared & 0.438 & 0.445 & 0.446 & 0.445 & 0.433 & 0.440 \\
\hline
\end{tabular}

Note: individual data. Communication represents the Communication-Index as defined in Section 4. Specialisation refers to the RSI, diversity to the $R D I$ as defined in Section 3. City size is measures in standardised logs. Dominant industry is a dummy variable indicating whether the worker works in the local dominant industry or not. The dominant local industry obtains the highest specialisation level. Highschool graduates are the reference group for education. Communication job refers to the importance of communication work activities in the job as defined in section 4. See Appendix $\mathrm{C}$ for a detailed description of the variables, measurement and data sources. Regressions also include a constant. Clustered standard errors in parentheses, ${ }^{*}$ significant at the $10 \%$ level, ${ }^{* *}$ significant at the $5 \%$ level, ${ }^{* * *}$ significant at the $1 \%$ level. 


\subsection{Instruments}

\section{Communication}

We construct a language-skill proxy as an instrument for communication job tasks. ${ }^{8}$ We assume workers with weaker language-skills to be less likely to perform communication job tasks. Transformation of tacit knowledge is key to communication job tasks and strongly affected by language-skills. Language-skills are proxied by information on the country of birth of the worker and the parents of the worker. The country of birth indicates the mother-tongue of the worker. We assume workers who grew up in an English speaking household to obtain better language-skills (in the US) than workers who grew up in a non-English speaking household. The language-skill proxy obtains four values which are described in table C3 in Appendix C.

Our instrument should be exogenous and not affecting wage via other channels than communication. Clearly, the country of birth is not chosen by the individual and is exogenous. However, we do not observe the actual household language which might be endogenous. We assume such an effect to be negligible. Another possible issue with the proxy is that it might capture the sorting of migrants into certain cities. Figures D1 and D2 in Appendix D present the relations between city's specialisation level, diversity level and communication level and the average native share in local occupations. The proxy does not seem to capture such sorting patterns.

Language-skills may affect wages via other channels than communication. For instance, the language-skill proxy captures cultural differences which could affect wage as well. Lewis (2011) finds that this effect is rather small. We test the validity of the instrument in Table 4. The first column shows a wage regression including both communication job tasks and the language-skill proxy. After controlling for communication, the language-skill proxy does not affect wage. Columns (2) and (3) show the OLS-estimates for communication and physical job tasks. Physical tasks are defined as 'handling and moving objects' and correlate negatively with wage. The next two columns (4 and 5) show the first stage results for IV-estimates instrumenting respectively communication and physical job tasks with the language-skill proxy. The proxy correlates strongly with communication jobs tasks and not with physical job tasks. Columns (6) and (7) present the IV-estimates. The IV-estimates for communication (column (6)) correspond with the OLS-estimates. The IV-estimates for physical tasks are insignificant. The significant wage effect of physical tasks diminishes in the IV-estimates. These results indicate that our language-skill proxy does not measure a cultural wage effect.

\section{Specialisation and diversity}

Ciccone and Hall (1996) introduced the standard way to tackle the endogeneity problem of city size and productivity. The spatial population distribution in the US is (to some extent) persistent over time. The division of employment across cities is remarkably constant. Thus, the size of a city today can be predicted by the size of the city many decades ago. Today's main drivers of productivity strongly differ from the historical drivers. Thus, historical population of a city strongly correlates with today's city size but does not affect the current wages in the city. Clearly, today's wages cannot affect historical city population. This makes historical population a valid instrument for current city size, at least when the instrument is measured in the far past. For an extensive discussion on the validity and exogeneity of historical population as an instrument we refer to the work of Ciccone and Hall (1996) and Combes e.a. (2009).

The sectoral specialisation and diversity of cities is correlated with size (respectively -0.66 and 0.57 , significant at the 1 percent level). Therefore, we instrument sectoral specialisation and diversity with population in 1930 .

\footnotetext{
${ }^{8}$ Charlot and Duranton (2004) instrument communication job tasks with the use of computers and internet at the work floor. The Current Population Survey includes similar information for the year 2000. However, we cannot rule out possible endogeneity of computer use. Workers may sort by ability into communication and computer intensive jobs for the same reasoning. Specification tests underline that computer use at the job is endogenous.
} 
Table 4: Instrumental variables are valid

\begin{tabular}{|c|c|c|c|c|c|c|c|}
\hline & \multicolumn{3}{|c|}{ OLS-estimates } & \multicolumn{2}{|c|}{ IV-estimates: first stage } & \multicolumn{2}{|c|}{ IV-estimates: second stage } \\
\hline & $\begin{array}{l}\text { Wage } \\
\text { (1) }\end{array}$ & $\begin{array}{c}\text { Communication } \\
\text { (2) }\end{array}$ & $\begin{array}{l}\text { Physical } \\
\text { (3) }\end{array}$ & $\begin{array}{c}\text { Communication } \\
\text { (4) }\end{array}$ & $\begin{array}{c}\text { Physical } \\
\text { (5) }\end{array}$ & $\begin{array}{c}\text { Communication } \\
\text { (6) }\end{array}$ & $\begin{array}{l}\text { Physical } \\
\text { (7) }\end{array}$ \\
\hline Communication & $\begin{array}{c}0.096 * * * \\
{[0.023]}\end{array}$ & $\begin{array}{c}0.098^{* * *} \\
{[0.019]}\end{array}$ & & & & $\begin{array}{c}0.109 * * * \\
{[0.042]}\end{array}$ & \\
\hline $\begin{array}{l}\text { Language-skill } \\
\text { proxy }\end{array}$ & $\begin{array}{c}0.006 \\
{[0.021]}\end{array}$ & & & $\begin{array}{c}0.434^{* * *} \\
{[0.097]}\end{array}$ & $\begin{array}{c}0.008 \\
{[0.072]}\end{array}$ & & \\
\hline Physical & & & $\begin{array}{c}-0.058^{*} \\
{[0.031]}\end{array}$ & & & & $\begin{array}{c}5.837 \\
{[52.293]}\end{array}$ \\
\hline Specialisation & $\begin{array}{c}-0.038^{* * *} \\
{[0.004]}\end{array}$ & $\begin{array}{c}-0.038^{* * *} \\
{[0.004]}\end{array}$ & $\begin{array}{c}-0.037^{* * *} \\
{[0.004]}\end{array}$ & $\begin{array}{l}-0.001 \\
{[0.004]}\end{array}$ & $\begin{array}{c}0.016^{* *} \\
{[0.007]}\end{array}$ & $\begin{array}{c}-0.038^{* * *} \\
{[0.004]}\end{array}$ & $\begin{array}{l}-0.132 \\
{[0.859]}\end{array}$ \\
\hline Diversity & $\begin{array}{c}-0.009 * * * \\
{[0.004]}\end{array}$ & $\begin{array}{c}-0.009 * * * \\
{[0.004]}\end{array}$ & $\begin{array}{c}-0.009 * * \\
{[0.004]}\end{array}$ & $\begin{array}{c}0.003 \\
{[0.003]}\end{array}$ & $\begin{array}{c}0.007 \\
{[0.006]}\end{array}$ & $\begin{array}{c}-0.009 * * * \\
{[0.004]}\end{array}$ & $\begin{array}{l}-0.051 \\
{[0.385]}\end{array}$ \\
\hline Dominant industry & $\begin{array}{c}-0.184^{* * *} \\
{[0.014]}\end{array}$ & $\begin{array}{c}-0.185^{* * *} \\
{[0.014]}\end{array}$ & $\begin{array}{c}-0.201 * * * \\
{[0.013]}\end{array}$ & $\begin{array}{c}-0.050^{* *} \\
{[0.023]}\end{array}$ & $\begin{array}{c}0.056^{* *} \\
{[0.022]}\end{array}$ & $\begin{array}{c}-0.183^{* * *} \\
{[0.015]}\end{array}$ & $\begin{array}{l}-0.517 \\
{[2.891]}\end{array}$ \\
\hline DOM*specialisation & $\begin{array}{c}0.069 * * * \\
{[0.008]}\end{array}$ & $\begin{array}{c}0.069 * * * \\
{[0.008]}\end{array}$ & $\begin{array}{c}0.079 * * * \\
{[0.009]}\end{array}$ & $\begin{array}{c}0.063^{* * *} \\
{[0.016]}\end{array}$ & $\begin{array}{c}-0.022 \\
{[0.023]}\end{array}$ & $\begin{array}{c}0.068^{* * *} \\
{[0.009]}\end{array}$ & $\begin{array}{c}0.202 \\
{[1.117]}\end{array}$ \\
\hline Drop-out & $\begin{array}{c}0.348^{* * *} \\
{[0.020]}\end{array}$ & $\begin{array}{c}0.348^{* * *} \\
{[0.020]}\end{array}$ & $\begin{array}{c}0.351^{* * *} \\
{[0.019]}\end{array}$ & $\begin{array}{c}0.108^{* * *} \\
{[0.029]}\end{array}$ & $\begin{array}{c}-0.212^{* * *} \\
{[0.044]}\end{array}$ & $\begin{array}{c}0.346 * * * \\
{[0.021]}\end{array}$ & $\begin{array}{c}1.594 \\
{[11.041]}\end{array}$ \\
\hline College & $\begin{array}{c}-0.041^{* * *} \\
{[0.013]}\end{array}$ & $\begin{array}{c}-0.041^{* * *} \\
{[0.013]}\end{array}$ & $\begin{array}{c}-0.014 \\
{[0.015]}\end{array}$ & $\begin{array}{c}0.175^{* * *} \\
{[0.051]}\end{array}$ & $\begin{array}{c}0.060 \\
{[0.070]}\end{array}$ & $\begin{array}{c}-0.043^{* *} \\
{[0.017]}\end{array}$ & $\begin{array}{l}-0.373 \\
{[3.293]}\end{array}$ \\
\hline College grad & $\begin{array}{c}0.047^{* * *} \\
{[0.003]}\end{array}$ & $\begin{array}{c}0.047^{* * *} \\
{[0.003]}\end{array}$ & $\begin{array}{c}0.046^{* * *} \\
{[0.003]}\end{array}$ & $\begin{array}{l}-0.002 \\
{[0.003]}\end{array}$ & $\begin{array}{c}-0.007^{* *} \\
{[0.004]}\end{array}$ & $\begin{array}{c}0.047^{* * *} \\
{[0.003]}\end{array}$ & $\begin{array}{c}0.090 \\
{[0.389]}\end{array}$ \\
\hline Rent & $\begin{array}{c}0.119 * * * \\
{[0.023]}\end{array}$ & $\begin{array}{c}0.118^{* * *} \\
{[0.023]}\end{array}$ & $\begin{array}{c}0.100 * * * \\
{[0.028]}\end{array}$ & $\begin{array}{c}-0.086 * * \\
{[0.039]}\end{array}$ & $\begin{array}{c}-0.080 \\
{[0.055]}\end{array}$ & $\begin{array}{c}0.120 * * * \\
{[0.024]}\end{array}$ & $\begin{array}{c}0.577 \\
{[4.205]}\end{array}$ \\
\hline Communication job & $\begin{array}{c}0.064^{* * *} \\
{[0.018]}\end{array}$ & $\begin{array}{c}0.065^{* * *} \\
{[0.018]}\end{array}$ & $\begin{array}{c}0.068^{* * *} \\
{[0.018]}\end{array}$ & $\begin{array}{l}-0.022 \\
{[0.037]}\end{array}$ & $\begin{array}{c}0.041 \\
{[0.042]}\end{array}$ & $\begin{array}{c}0.065^{* * *} \\
{[0.018]}\end{array}$ & $\begin{array}{l}-0.174 \\
{[2.179]}\end{array}$ \\
\hline Non-white & $\begin{array}{c}-0.081 * * * \\
{[0.007]}\end{array}$ & $\begin{array}{c}-0.082^{* * *} \\
{[0.007]}\end{array}$ & $\begin{array}{c}-0.084^{* * *} \\
{[0.008]}\end{array}$ & $\begin{array}{c}-0.004 \\
{[0.016]}\end{array}$ & $\begin{array}{c}0.015 \\
{[0.016]}\end{array}$ & $\begin{array}{c}-0.081^{* * *} \\
{[0.007]}\end{array}$ & $\begin{array}{c}-0.170 \\
{[0.846]}\end{array}$ \\
\hline Non-married & $\begin{array}{c}-0.055^{* * *} \\
{[0.006]}\end{array}$ & $\begin{array}{c}-0.055^{* * *} \\
{[0.006]}\end{array}$ & $\begin{array}{c}-0.056 * * * \\
{[0.006]}\end{array}$ & $\begin{array}{c}-0.014 \\
{[0.009]}\end{array}$ & $\begin{array}{c}0.006 \\
{[0.011]}\end{array}$ & $\begin{array}{c}-0.055^{* * *} \\
{[0.006]}\end{array}$ & $\begin{array}{c}-0.090 \\
{[0.301]}\end{array}$ \\
\hline Age & $\begin{array}{c}0.049 * * * \\
{[0.003]}\end{array}$ & $\begin{array}{c}0.048 * * * \\
{[0.003]}\end{array}$ & $\begin{array}{c}0.049 * * * \\
{[0.003]}\end{array}$ & $\begin{array}{c}0.010 * * \\
{[0.004]}\end{array}$ & $\begin{array}{c}-0.006 \\
{[0.006]}\end{array}$ & $\begin{array}{c}0.048^{* * *} \\
{[0.003]}\end{array}$ & $\begin{array}{c}0.084 \\
{[0.306]}\end{array}$ \\
\hline Age square & $\begin{array}{c}-0.000 * * * \\
{[0.000]}\end{array}$ & $\begin{array}{c}-0.000^{* * *} \\
{[0.000]}\end{array}$ & $\begin{array}{c}-0.000 * * * \\
{[0.000]}\end{array}$ & $\begin{array}{c}-0.000 * * \\
{[0.000]}\end{array}$ & $\begin{array}{c}0.000 \\
{[0.000]}\end{array}$ & $\begin{array}{c}-0.000^{* * *} \\
{[0.000]}\end{array}$ & $\begin{array}{c}-0.001 \\
{[0.004]}\end{array}$ \\
\hline Female & $\begin{array}{c}-0.183^{* * *} \\
{[0.013]}\end{array}$ & $\begin{array}{c}-0.183^{* * *} \\
{[0.013]}\end{array}$ & $\begin{array}{c}-0.182^{* * *} \\
{[0.013]}\end{array}$ & $\begin{array}{l}-0.027 \\
{[0.032]}\end{array}$ & $\begin{array}{c}0.043 \\
{[0.052]}\end{array}$ & $\begin{array}{c}-0.182^{* * *} \\
{[0.013]}\end{array}$ & $\begin{array}{l}-0.435 \\
{[2.255]}\end{array}$ \\
\hline $\begin{array}{l}\text { Occupation } \\
\text { dummies }\end{array}$ & YES*** & YES*** & YES*** & YES*** & YES*** & YES*** & YES*** \\
\hline Observations & 82705 & 82705 & 82705 & 82705 & 82705 & 82705 & 82705 \\
\hline R-squared & 0.445 & 0.445 & 0.441 & 0.736 & 0.626 & 0.445 & \\
\hline F-test & & & & 19.81 & 0.01 & & \\
\hline
\end{tabular}

Note: individual data. See Appendix C for a detailed description of the variables, measurement and data sources. Regressions also include a constant. Clustered standard errors in parentheses, ${ }^{*}$ significant at the $10 \%$ level, ${ }^{* *}$ significant at the $5 \%$ level, ${ }^{* * *}$ significant at the $1 \%$ level. 
The MSA population in 1930 is composed using Census Historical County Population figures. For each county this database includes decennial information on its population. We include population in 1930 as this is the first year with a decent covering across counties. Next, we sum county population by MSA (1990 definition) to construct MSA population in 1930. The MSA population in 1930 varies between 9,897 and 7,524,736 inhabitants.

\subsection{Relevance of the instruments}

Before we turn to the IV-estimates we test the relevance of our instruments. The correlation between population in 1930 and sectoral specialisation in 2009 is -0.51 and significant at the 1 percent level. For sectoral diversity this correlation is 0.61 (significant at the 1 percent level). Also the instrument of communication is strongly correlated with the communication index $(0.58$, significant at the 1 percent level).

Columns (1) and (2) of Table 5 show the first stage estimates for communication job tasks. In column (1) we include the city's sectoral specialisation and diversity level as explanatory variables while in column (2) we include city's population in 1930. The language-skill proxy seems to be a sound instrument for communication. Natives are relatively more present in communicationintensive occupations. The covariates show the usual sign and coefficients. By definition, the communication intensity of occupations does not vary across cities which explain the insignificant coefficients of historical and sectoral structure. ${ }^{9}$ Communication work activities (waiting tables e.g.) and communication job tasks (communicating about work activities) are positively correlated. The Fstatistics show that the instrument for communication is valid. ${ }^{10}$ Columns (3) and (4) present the first stage results for sectoral specialisation, with and without instrumenting communication as well. To produce interpretable results, we include the log of historical population. Historical city size is a decent predictor for current sectoral specialisation. The F-statistics indicate that historical population is a valid instrument for current specialisation level. Lastly, columns (5) and (6) show the first stage estimates for the industrial diversity level of cities. Historical city size predicts current sectoral diversity even more precise than it predicts current sectoral specialisation. In diversified cities, workers perform more communication work activities while communication about these activities is indifferent from the average.

\subsection{Results}

Table 6 presents the IV-estimates. As in Table 3 the returns to communication are allowed to vary with city specialisation level, diversity level and city size. For each city characteristic (specialisation, diversity and size) we first present the baseline regression in which communication is instrumented with our language-skill proxy and the characteristic with population in 1930. The next column shows the IV-estimates with additional cross-terms between the language-skill proxy and the city characteristics. The IV-estimates provide similar results as the OLS-estimates.

The returns to communication remain positive and significant. An increase of the communication job tasks of one standard deviation raises the individual wage with about $18 \%$ of a standard deviation. The returns to communication are about $16 \%$ of a standard deviation in specialised cities (column (2)).

In large cities the returns to communication are somewhat higher (about $21 \%$, column (6)). The coefficient of the cross-term between communication and diversity level becomes insignificant (column (4)). Especially in large, not specialised cities workers earn more when they perform more communication tasks.

The variation in returns to communication between different city types partly explains the lower wages in specialised cities. The negative specialisation wage premium decrease from $9 \%$ of a standard deviation to $8 \%$. The urban wage premium decrease from $4 \%$ of a standard deviation to $2 \%$ of a standard deviation.

\footnotetext{
${ }^{9}$ The importance of communication is measured at the occupation level and independent of location.

${ }^{10} \mathrm{~F}$-statistics are generated for the additional instruments only (communication and population in 1930).
} 
Table 5: First stage regressions

\begin{tabular}{|c|c|c|c|c|c|c|}
\hline & $\begin{array}{c}\text { Communica } \\
\text { (1) }\end{array}$ & (2) & $\begin{array}{c}\text { Specialisation } \\
\text { (3) }\end{array}$ & (4) & $\begin{array}{c}\text { Diversity } \\
\text { (5) }\end{array}$ & (6) \\
\hline \multirow[t]{2}{*}{ Language-skill proxy } & $0.434 * * *$ & $0.434 * * *$ & & 0.010 & & -0.013 \\
\hline & {$[0.097]$} & {$[0.097]$} & & {$[0.013]$} & & [0.008] \\
\hline \multirow[t]{2}{*}{ Population 1930} & & 0.001 & $-0.372 * * *$ & $-0.372 * * *$ & $0.477 * * *$ & $0.477 * * *$ \\
\hline & & {$[0.002]$} & {$[0.005]$} & [0.005] & {$[0.003]$} & {$[0.003]$} \\
\hline \multirow[t]{2}{*}{ Communication } & & & -0.003 & & 0.006 & \\
\hline & & & {$[0.011]$} & & [0.007] & \\
\hline \multirow[t]{2}{*}{ Specialisation } & -0.001 & & & & & \\
\hline & {$[0.004]$} & & & & & \\
\hline \multirow[t]{2}{*}{ Diversity } & 0.003 & & & & & \\
\hline & [0.003] & & & & & \\
\hline \multirow[t]{2}{*}{ Dominant industry } & $-0.086^{* *}$ & $-0.088^{* *}$ & $-0.214 * * *$ & $-0.212^{* * *}$ & $-0.580 * * *$ & $-0.582^{* * *}$ \\
\hline & [0.039] & [0.039] & [0.068] & [0.068] & [0.059] & [0.058] \\
\hline \multirow[t]{2}{*}{ DOM*specialisation } & -0.022 & -0.023 & $0.845^{* * *}$ & $0.845^{* * *}$ & $0.135^{*}$ & $0.136^{*}$ \\
\hline & [0.037] & [0.039] & {$[0.036]$} & {$[0.036]$} & {$[0.072]$} & [0.071] \\
\hline \multirow[t]{2}{*}{ Drop-out } & $-0.050 * *$ & $-0.050 * *$ & -0.023 & -0.020 & -0.023 & $-0.028 *$ \\
\hline & {$[0.023]$} & {$[0.023]$} & [0.015] & {$[0.014]$} & [0.015] & [0.015] \\
\hline \multirow[t]{2}{*}{ College } & $0.063 * * *$ & $0.063 * * *$ & $0.041 * * *$ & $0.040 * * *$ & $0.021 * * *$ & $0.023 * * *$ \\
\hline & {$[0.016]$} & {$[0.016]$} & [0.009] & [0.009] & [0.007] & {$[0.007]$} \\
\hline \multirow[t]{2}{*}{ College grad } & $0.108 * * *$ & $0.109 * * *$ & $-0.035 * * *$ & $-0.036 * * *$ & -0.009 & -0.007 \\
\hline & [0.029] & [0.029] & [0.010] & [0.010] & [0.015] & [0.015] \\
\hline \multirow[t]{2}{*}{ Communication job } & $0.175^{* * *}$ & $0.175^{* * *}$ & -0.000 & -0.003 & $0.016 * * *$ & $0.020 * * *$ \\
\hline & {$[0.051]$} & {$[0.051]$} & {$[0.007]$} & {$[0.007]$} & [0.006] & [0.006] \\
\hline \multirow[t]{2}{*}{ Rent } & -0.002 & -0.001 & $-0.277 * * *$ & $-0.277 * * *$ & $0.051 * * *$ & $0.051^{* * *}$ \\
\hline & [0.003] & {$[0.003]$} & {$[0.006]$} & {$[0.006]$} & [0.005] & {$[0.005]$} \\
\hline \multirow[t]{2}{*}{ Non-white } & -0.004 & -0.004 & $-0.162 * * *$ & $-0.161 * * *$ & $-0.101 * * *$ & $-0.102 * * *$ \\
\hline & {$[0.016]$} & {$[0.016]$} & [0.010] & [0.010] & [0.010] & {$[0.010]$} \\
\hline \multirow[t]{2}{*}{ Non-married } & -0.014 & -0.014 & $-0.040 * * *$ & $-0.040 * * *$ & $-0.014 * *$ & $-0.014 * *$ \\
\hline & [0.009] & [0.009] & {$[0.008]$} & {$[0.008]$} & {$[0.007]$} & [0.007] \\
\hline \multirow[t]{2}{*}{ Age } & $0.010 * *$ & $0.010 * *$ & $-0.007 * * *$ & $-0.007 * * *$ & $0.004^{* *}$ & $0.004 * *$ \\
\hline & {$[0.004]$} & [0.004] & [0.002] & [0.002] & [0.002] & [0.002] \\
\hline \multirow[t]{2}{*}{ Age square } & $-0.000 * *$ & $-0.000 * *$ & $0.000 * * *$ & $0.000 * * *$ & $-0.000^{*}$ & $-0.000 *$ \\
\hline & {$[0.000]$} & {$[0.000]$} & {$[0.000]$} & {$[0.000]$} & {$[0.000]$} & [0.000] \\
\hline \multirow[t]{2}{*}{ Female } & -0.027 & -0.027 & $0.023 * * *$ & $0.023 * * *$ & -0.012 & -0.012 \\
\hline & [0.032] & [0.032] & [0.008] & {$[0.008]$} & {$[0.007]$} & {$[0.007]$} \\
\hline Occupation dummies & $1.464 * * *$ & $1.465^{* * *}$ & $-0.139 * * *$ & $-0.154 * * *$ & -0.026 & -0.004 \\
\hline Observations & 82705 & 82705 & 82705 & 82705 & 82705 & 82705 \\
\hline R-squared & 0.736 & 0.736 & 0.365 & 0.365 & 0.383 & 0.383 \\
\hline
\end{tabular}

Note: individual data. See Appendix C for a detailed description of the variables, measurement and data sources. F-test for additional instruments communication and population 1930. Regressions also include a constant. Clustered standard errors in parentheses, * significant at the $10 \%$ level, ${ }^{* *}$ significant at the $5 \%$ level, ${ }^{* * *}$ significant at the $1 \%$ level. 
Table 6: IV-estimates

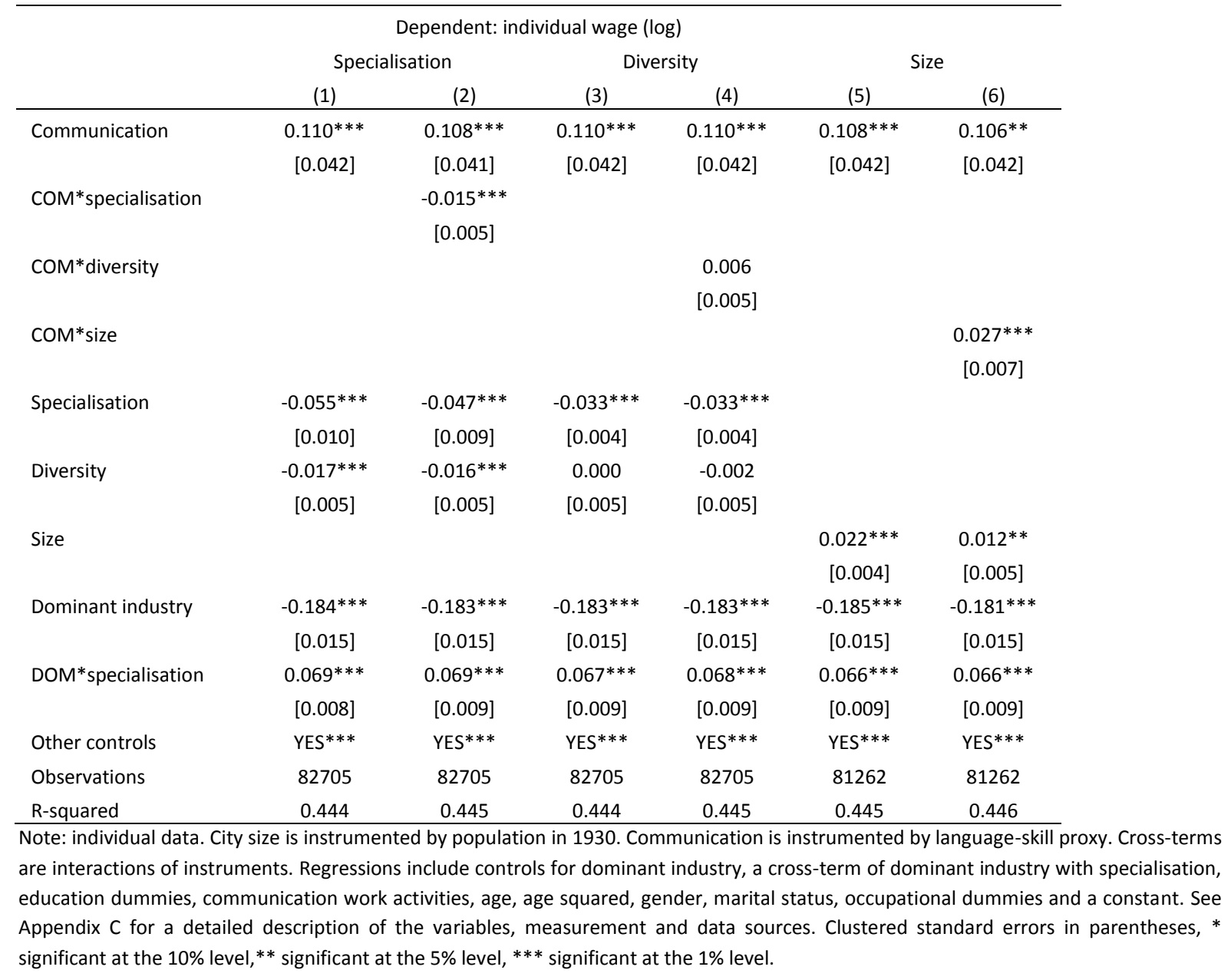

\section{Robustness}

We test the robustness of our estimates by considering four robustness checks. Here, we only present the IV-estimates including the cross-term between communication job tasks and local specialisation level. The OLS-estimates and IV-estimates including the other cross-terms provide similar results and are available upon request. First, we test the sensitivity of the results towards the measure of communication (section 7.1). Second, section 7.2 discusses an additional test for the impact of unobserved ability. Next, we add cross-terms between communication and individual skill level to our analyses (section 7.3). Lastly, the measure of local specialisation level is put to the test (section 7.4).

\subsection{Other measures of communication}

To address the validity of our results we test three alternative ways to measure communication job tasks. First, we measure communication job tasks as the share of all job tasks. This indicator measures the importance of communication relative to other job tasks instead of the absolute importance of communication. Columns (1) and (2) in Table 7 presents the IV-estimates. The relative returns to communication are significantly larger than the absolute returns to communication. An increase of one standard deviation in relative communication leads to an increase of $41 \%$ of a wage standard deviation. Within specialised cities this return is only $32 \%$ of a standard deviation. The 
returns to communication do not differ across local diversifications level while the returns in large cities are $52 \%$ of a standard deviation.

Second, we consider the wage returns to non-routine interactive tasks. Information and communication technology (ICT) acts as a substitute for some tasks and a complement for others (e.g., Autor e.a. (2003)). Computer technology replaces labour in performing routine tasks that can easily be described with programmed rules, such as the repetitive tasks of clerks and cashiers (Bresnahan (1999)). On the other hand, non-routine tasks, such as managing others, legal writing and selling, cannot, as of yet, be described as a set of programmable rules. Non-routine tasks require an adaptive attitude of the worker; these are typically tasks involving communication, interaction and knowledge transfer. The rival effects of computer technology on routine tasks on the one hand and non-routine on the other hand relate to the rival spatial effects of technology as indicated by Glaeser and Ponzetto (2007), Gaspar and Glaeser (1998) and loannides e.a. (2008)). Autor and Dorn (2010)) show that cities with initially specialisation in routine-intensive occupations obtain employment and wage polarization after 1980 . Clearly, non-routine interactive and communication tasks are strongly related $(0.72$, significant at the 1 percent level). The first stage regression shows a strong correlation between the language-skills proxy and the non-routine interactive tasks of an occupation ${ }^{11}$. Columns (3) and (4) of Table 7 present the IV-estimates with the linear and cross-terms of non-routine interactive tasks instead of communication job tasks. The IV-estimates indicate a positive return to the performance of non-routiness interactive tasks of about $25 \%$ of a standard deviation. This return is - as expected - somewhat lower in specialised cities (about $21 \%$ of a standard deviation) and somewhat higher in diversified cities (about $30 \%$ of a standard deviation).

The last measure of communication stems from the work of Borghans e.a. (2006) and Bacolod e.a. (2009) and measures the interpersonal skill requirements of the job: the importance of 'people skills'. We calculate the importance of 'people skills' by the importance of six ONET skill variables: social perspectives, coordination, persuasion, negotiation, instruction and service orientation. The last three columns of Table 7 present the results. Including people skills instead of communication job tasks does not change the results. There are positive wage returns to the performance of people skills in cities, these returns increase with the size of city and decrease with the specialisation level of the city.

\subsection{Unobserved ability}

Sorting of workers by unobserved ability is a commonly acknowledged measurement issue for spatial wage estimations (e.g. Combes e.a. (2008)). Ideally, we would eliminate unobserved worker heterogeneity using a large panel of individuals. The CPS is not a panel but has a time dimension. We aggregate the individual data to the city level (MSA) to obtain a panel of cities. Additionally to our IVestimates we take the first difference of local variables and remove the unobserved ability bias using the time dimension.

As discussed in section 3.2, unobserved ability $\left(A_{k}\right)$ could cause biased estimates when it correlates with other explanatory variables. We assume that unobserved ability $A_{k}$ (such as personal talent, ambition and work discipline) is time invariant. Taking the first difference removes the eventual ability bias. To do so, we add a time dimension to equation (11):

$\ln w_{k i t}=\alpha_{1}+\alpha_{2} \hat{\varphi}_{k}+\alpha_{3} \widehat{M}_{k t}+\beta_{1} \hat{\theta}_{k t}+\beta_{2} \hat{\rho}_{i t}+\beta_{3} \hat{R}_{i t}+\gamma_{1}\left(\hat{\theta}_{k t} \cdot \hat{\rho}_{i t}\right)+\gamma_{2}\left(\widehat{M}_{k t} \cdot \hat{\rho}_{i t}\right)+\varepsilon_{k i t}$

\footnotetext{
${ }^{11}$ The index is defined as in Acemoglu and Autor (2011). The index is standardised with mean 0 and standard deviation 1. Data Appendix C describes the measurement of this index.
} 
Table 7: Other measures of communication - IV-estimates

\begin{tabular}{|c|c|c|c|c|c|c|}
\hline & \multicolumn{6}{|c|}{ Dependent: individual wage (log) } \\
\hline & \multicolumn{2}{|c|}{ Relative communication } & \multicolumn{2}{|c|}{ Non-routine interactive } & \multicolumn{2}{|c|}{ People skills } \\
\hline & (1) & $(2)$ & (3) & (4) & $(5)$ & (6) \\
\hline \multirow[t]{2}{*}{ Communication } & $0.264 * *$ & $0.259^{* *}$ & $0.162^{* *}$ & $0.160^{* *}$ & $0.133^{* * *}$ & $0.131 * * *$ \\
\hline & {$[0.132]$} & {$[0.131]$} & {$[0.077]$} & {$[0.077]$} & {$[0.049]$} & {$[0.049]$} \\
\hline \multirow[t]{2}{*}{$\mathrm{COM}^{*}$ specialisation } & & $-0.047^{* * *}$ & & $-0.023 * * *$ & & $-0.019 * * *$ \\
\hline & & {$[0.016]$} & & [0.008] & & {$[0.006]$} \\
\hline \multirow[t]{2}{*}{ Specialisation } & $-0.049 * * *$ & -0.005 & $-0.058 * * *$ & $-0.057 * * *$ & $-0.052 * * *$ & $-0.042 * * *$ \\
\hline & {$[0.010]$} & {$[0.020]$} & {$[0.011]$} & {$[0.011]$} & {$[0.010]$} & {$[0.010]$} \\
\hline \multirow[t]{2}{*}{ Diversity } & $-0.013^{* * *}$ & $-0.012 * *$ & $-0.018^{* * *}$ & $-0.017^{* * *}$ & $-0.015^{* * *}$ & $-0.014^{* * *}$ \\
\hline & {$[0.005]$} & {$[0.005]$} & [0.006] & [0.006] & {$[0.005]$} & {$[0.005]$} \\
\hline \multirow[t]{2}{*}{ Dominant industry } & $0.104^{* * *}$ & $0.099 * * *$ & $0.122^{* * *}$ & $0.120 * * *$ & $0.114^{* * *}$ & $0.110^{* * *}$ \\
\hline & {$[0.024]$} & {$[0.024]$} & {$[0.030]$} & {$[0.029]$} & {$[0.030]$} & {$[0.030]$} \\
\hline \multirow[t]{2}{*}{ DOM*specialisation } & $0.086 * * *$ & $0.080 * * *$ & $0.080 * * *$ & $0.075^{* * *}$ & $0.081^{* * *}$ & $0.073^{* * *}$ \\
\hline & {$[0.020]$} & [0.019] & {$[0.021]$} & {$[0.021]$} & {$[0.021]$} & {$[0.021]$} \\
\hline Other controls & YES*** & YES*** & YES*** & YES*** & YES*** & YES*** \\
\hline Observations & 82705 & 82705 & 82705 & 82705 & 82705 & 82705 \\
\hline R-squared & 0.413 & 0.414 & 0.412 & 0.412 & 0.435 & 0.436 \\
\hline
\end{tabular}

Note: individual data. Relative communication is the importance of communication relative to all other work activities and work context. Non-routine interactive tasks are measured as in Acemoglu and Autor (2011). Regressions include controls for dominant industry, a crossterm of dominant industry with specialisation, education dummies, communication work activities, age, age squared, gender, marital status, occupational dummies and a constant. See Appendix $\mathrm{C}$ for a detailed description of the variables, measurement and data sources. Clustered standard errors in parentheses, ${ }^{*}$ significant at the $10 \%$ level, ${ }^{* *}$ significant at the $5 \%$ level, ${ }^{* * *}$ significant at the $1 \%$ level.

Individual ability $\left(\hat{\varphi}_{k}\right)$ is constant over time $t$. The amount of communication tasks the worker performs $\left(\hat{\theta}_{k t}\right)$, the specialisation level $\left(\hat{\rho}_{i t}\right)$ and the size of the city $\left(\hat{R}_{i t}\right)$ might change over time. The measurement error includes the ability of worker $k\left(A_{k}\right.$ which is constant over time and place) and some measurement error at the individual, city, time level $\left(\mu_{k i t}\right): \varepsilon_{k i}=A_{k}+\mu_{k i}$.

To obtain a panel of cities we aggregate all indicators to the city level $i$ :

$\Delta \ln w_{k i}=\alpha_{2} \hat{\varphi}_{i}+\alpha_{3} \Delta \widehat{M}_{i}+\beta_{1} \Delta \hat{\theta}_{i}+\beta_{2} \Delta \hat{\rho}_{i}+\beta_{3} \Delta \hat{R}_{i}+\gamma_{1}\left(\Delta \hat{\theta}_{i} \cdot \Delta \hat{\rho}_{i}\right)+\gamma_{2}\left(\Delta \widehat{M}_{i} \cdot \Delta \hat{\rho}_{i}\right)+\Delta \varepsilon_{i}(14)$

in which $\Delta \varepsilon_{i}$ does not include unobserved ability. Table 8 presents the estimates of this model for the period 2006-2009. The results hold for several time periods. The estimates resemble the IVestimates. The change in communication tasks at the MSA level between 2006 and 2009 is positively related with the change in MSA wage. The coefficients of the cross-term with sector specialisation is negative and significant, the cross-term with diversity insignificant and the cross-term with size positive and significant.

\subsection{Skill level}

Especially the spatial clustering of high skilled workers relates to higher local wages (Glaeser and Mare (2001) and Glaeser and Gottlieb (2009)). Skilled workers cluster in certain cities (e.g. New York, San Francisco) and these cities tend to be the ones with higher wages (Rauch (1993)) and higher growth rates (Glaeser e.a. (1995)). Table 5 showed strong correlations between the sectoral 
Table 8: First differences at MSA level

\begin{tabular}{|c|c|c|c|c|c|}
\hline & \multicolumn{4}{|c|}{ Dependent: change in average MSA wage (2006-2009) } & \multirow[b]{2}{*}{ (5) } \\
\hline & (1) & $(2)$ & (3) & (4) & \\
\hline \multirow[t]{2}{*}{ Communication } & & $0.086^{* * *}$ & $0.069 * * *$ & & $0.062 * * *$ \\
\hline & & [0.015] & {$[0.017]$} & & {$[0.017]$} \\
\hline \multirow[t]{2}{*}{ COM*specialisation } & & $-0.030 * * *$ & & & \\
\hline & & {$[0.005]$} & & & \\
\hline \multirow[t]{2}{*}{$\mathrm{COM}^{*}$ diversity } & & & 0.012 & & \\
\hline & & & [0.009] & & \\
\hline \multirow[t]{2}{*}{$\mathrm{COM}^{*}$ size } & & & & & $0.018^{* *}$ \\
\hline & & & & & {$[0.008]$} \\
\hline \multirow[t]{2}{*}{ Specialisation } & $-0.055^{* * *}$ & $-0.043 * * *$ & $-0.055^{* * *}$ & & \\
\hline & [0.002] & {$[0.002]$} & {$[0.001]$} & & \\
\hline \multirow[t]{2}{*}{ Diversity } & $-0.010 * * *$ & $-0.011 * * *$ & $-0.016 * * *$ & & \\
\hline & {$[0.002]$} & {$[0.002]$} & {$[0.004]$} & & \\
\hline \multirow[t]{2}{*}{ Size } & & & & -0.005 & $0.040 * * *$ \\
\hline & & & & [0.008] & {$[0.004]$} \\
\hline \multirow[t]{2}{*}{ Dominant industry } & 0.042 & 0.099 & 0.072 & $0.579 * *$ & $0.144^{* *}$ \\
\hline & [0.078] & {$[0.068]$} & {$[0.070]$} & {$[0.241]$} & {$[0.060]$} \\
\hline \multirow[t]{2}{*}{ DOM*specialisation } & $0.132^{* *}$ & $0.111^{* *}$ & $0.122^{* *}$ & $-0.372 * *$ & $0.070^{*}$ \\
\hline & {$[0.053]$} & {$[0.047]$} & {$[0.049]$} & [0.163] & [0.041] \\
\hline \multirow[t]{2}{*}{ Drop-out } & $-0.279 * * *$ & $-0.243 * * *$ & $-0.253 * * *$ & $-0.172 * *$ & $-0.250 * * *$ \\
\hline & [0.027] & [0.024] & [0.024] & {$[0.083]$} & {$[0.022]$} \\
\hline \multirow[t]{2}{*}{ College } & $0.094^{* * *}$ & $0.095 * * *$ & $0.096 * * *$ & 0.086 & $0.087^{* * *}$ \\
\hline & [0.019] & {$[0.016]$} & {$[0.017]$} & [0.059] & {$[0.015]$} \\
\hline \multirow[t]{2}{*}{ College grad } & $0.378 * * *$ & $0.378 * * *$ & $0.377 * * *$ & $0.429 * * *$ & $0.369 * * *$ \\
\hline & [0.023] & {$[0.020]$} & {$[0.021]$} & {$[0.072]$} & {$[0.019]$} \\
\hline \multirow[t]{2}{*}{ Rent } & -0.024 & $-0.030^{*}$ & -0.027 & -0.061 & $-0.029 * *$ \\
\hline & {$[0.018]$} & {$[0.016]$} & {$[0.016]$} & {$[0.057]$} & {$[0.015]$} \\
\hline \multirow[t]{2}{*}{ Communication job } & $-0.073 * * *$ & $-0.073 * * *$ & $-0.070 * * *$ & -0.026 & $-0.076 * * *$ \\
\hline & {$[0.016]$} & {$[0.014]$} & [0.015] & {$[0.051]$} & [0.013] \\
\hline \multirow[t]{2}{*}{ Non-white } & $0.009 * * *$ & $0.009 * * *$ & $0.009 * * *$ & $0.004^{* *}$ & $0.009 * * *$ \\
\hline & {$[0.001]$} & {$[0.001]$} & {$[0.001]$} & {$[0.002]$} & {$[0.000]$} \\
\hline \multirow[t]{2}{*}{ Non-married } & 0.000 & 0.000 & 0.000 & 0.000 & 0.000 \\
\hline & {$[0.000]$} & {$[0.000]$} & {$[0.000]$} & {$[0.000]$} & {$[0.000]$} \\
\hline \multirow[t]{2}{*}{ Age } & $-0.192^{* * *}$ & $-0.202 * * *$ & $-0.202^{* * *}$ & $-0.276^{* * *}$ & $-0.202^{* * *}$ \\
\hline & {$[0.024]$} & {$[0.021]$} & {$[0.022]$} & {$[0.077]$} & [0.019] \\
\hline \multirow[t]{2}{*}{ Age square } & $0.328 * * *$ & $0.247 * * *$ & $0.256 * * *$ & $0.385^{* * *}$ & $0.265^{* * *}$ \\
\hline & [0.032] & [0.037] & [0.039] & {$[0.103]$} & {$[0.034]$} \\
\hline \multirow[t]{2}{*}{ Female } & $0.241^{* * *}$ & $0.177^{* * *}$ & $0.180 * * *$ & $0.348 * * *$ & $0.200 * * *$ \\
\hline & [0.036] & {$[0.038]$} & {$[0.040]$} & {$[0.113]$} & {$[0.035]$} \\
\hline Occupation dummies & YES*** & YES*** & YES*** & YES*** & YES*** \\
\hline Observations & 165 & 165 & 165 & 165 & 165 \\
\hline R-squared & 0.981 & 0.986 & 0.985 & 0.807 & 0.988 \\
\hline
\end{tabular}

Note: city data (aggregated individual data). See Appendix C for a detailed description of the variables, measurement and data sources. Clustered standard errors in parentheses, ${ }^{*}$ significant at the $10 \%$ level, ${ }^{* *}$ significant at the $5 \%$ level, ${ }^{* * *}$ significant at the $1 \%$ level. 
Table 9: Additional variation: skill levels, industry and services. IV-estimates

\begin{tabular}{|c|c|c|c|c|}
\hline & \multicolumn{4}{|c|}{ Dependent: individual wage (log) } \\
\hline & \multicolumn{2}{|c|}{ Skill cross-terms } & \multirow{2}{*}{$\begin{array}{l}\text { Manufacturing } \\
\text { (3) }\end{array}$} & \multirow{2}{*}{$\begin{array}{c}\text { Services } \\
(4) \\
\end{array}$} \\
\hline & (1) & (2) & & \\
\hline \multirow[t]{2}{*}{ Communication } & $0.114 * * *$ & $0.113^{* * *}$ & $0.182 * * *$ & $0.125^{* * *}$ \\
\hline & {$[0.036]$} & {$[0.036]$} & {$[0.055]$} & {$[0.047]$} \\
\hline \multirow[t]{2}{*}{$\mathrm{COM}^{*}$ specialisation } & & $-0.016^{* * *}$ & $-0.069 * * *$ & -0.015 \\
\hline & & {$[0.005]$} & {$[0.021]$} & {$[0.009]$} \\
\hline \multirow[t]{2}{*}{$\mathrm{COM}^{*}$ drop-out } & -0.002 & -0.003 & & \\
\hline & {$[0.006]$} & {$[0.005]$} & & \\
\hline \multirow[t]{2}{*}{$\mathrm{COM}^{*}$ college } & 0.001 & 0.001 & & \\
\hline & {$[0.007]$} & {$[0.007]$} & & \\
\hline \multirow[t]{3}{*}{$\mathrm{COM}^{*}$ college grad } & -0.013 & -0.015 & & \\
\hline & {$[0.041]$} & {$[0.041]$} & & \\
\hline & - & & & \\
\hline \multirow[t]{2}{*}{ Specialisation } & $0.055^{* * *}$ & $-0.048 * * *$ & $-0.037 * * *$ & $-0.047 * * *$ \\
\hline & [0.010] & [0.010] & {$[0.008]$} & {$[0.006]$} \\
\hline \multirow[t]{2}{*}{ Diversity } & $0.017^{* * *}$ & $-0.016 * * *$ & -0.002 & 0.001 \\
\hline & {$[0.005]$} & {$[0.005]$} & {$[0.003]$} & {$[0.017]$} \\
\hline \multirow[t]{2}{*}{ Dominant industry } & $0.114 * * *$ & $0.111^{* * *}$ & $0.120 * * *$ & $0.124 * * *$ \\
\hline & {$[0.023]$} & {$[0.023]$} & {$[0.023]$} & {$[0.024]$} \\
\hline \multirow[t]{2}{*}{ DOM*specialisation } & $0.081^{* * *}$ & $0.073 * * *$ & $0.058 * * *$ & $0.065^{* * *}$ \\
\hline & {$[0.020]$} & {$[0.019]$} & {$[0.018]$} & {$[0.019]$} \\
\hline Other controls & YES*** & YES*** & YES*** & YES*** \\
\hline Observations & 82705 & 82705 & 82705 & 82705 \\
\hline R-squared & 0.443 & 0.444 & 0.446 & 0.445 \\
\hline
\end{tabular}

Note: individual data. All variables are standardized with mean 0 and standard deviation 1 . Regressions include controls for dominant industry, a cross-term of dominant industry with specialisation, education dummies, communication work activities, age, age squared, gender, marital status, occupational dummies and a constant. See Appendix C for a detailed description of the variables, measurement and data sources. Clustered standard errors in parentheses, ${ }^{*}$ significant at the $10 \%$ level, ${ }^{* *}$ significant at the $5 \%$ level, $* * *$ significant at the $1 \%$ level.

structure of cities and the skill level of their inhabitants. Do high-skilled workers benefit more from performing communication tasks than low-skilled workers? The first two columns of Table 9 present the IV-estimates including cross-terms between communication and educational dummies. The cross-terms are insignificant while our variables of interest are hardly affected by the inclusion of these additional explanatory variables.

\subsection{Industrial structure}

Lastly, we test the sensitivity of the results to changes in the measure of the local industrial structure. The bias in the classification of sectors might hamper the estimates of our indicators for the local industrial specialisation and diversity level. Overall, manufacturing sectors are defined at a more detailed level in the classification than service sectors. A diverse local structure of manufacturing sectors therefore obtains a higher $R D I$ than a diverse local structure of service sectors. Indeed, the variation in specialisation and diversity in manufacturing sectors is larger than the variation in service sectors. The last column of Table 9 present IV-estimates in which only manufacturing sectors (column 3) and only service sectors (column 4) are included in the RSI. The returns to communication job tasks vary with the local specialisation level of both manufacturing and service sectors. As expected, the variation in the local manufacturing specialisation obtains a stronger impact than the variation in the local service sector. 


\section{Discussion}

The debate in the empirical literature and economic regional policy has been largely about stimulating fruitful environments. The success of clusters like Silicon Valley and diversified cities such as New York City stimulated many scientific and policy projects on this subject and incited a massive literature on agglomeration economies. Many papers focus on the question whether specialised or diversified cities are the most fruitful environments. Duranton and Puga (2001) were the first to point out that both types are important in a system of cities. The question remains however how to induce such a beneficial environment and whether the advantages of proximity are similar in both city types.

A major advantage of cities seems to lay in the role of proximity for the communication of tacit knowledge and for learning from each other. Jaffe e.a. (1993) show that distance bounds patent citation. Bacolod e.a. (2009) and Florida e.a. (2012) show that the returns to certain skills, such as social skills, increase with city size. Charlot and Duranton (2004) find positive returns to communication in French cities. This paper takes a step towards unravelling the advantages of specialised and diversified cities by analysing the role of communication in both city types. We show substantial wage returns to communication in both diversified and specialised US cities. Given their occupation, workers who communicate more are more valued by firms. These returns decrease however with the specialisation level of the urban area. Communication is positively valued in all city environments but plays more of a key role in diversified cities.

In line with the work of Duranton and Puga (2001) and Desmet and Rossi-Hansberg (2009) we relate these findings to differences in the production processes of firms across specialised and not-specialised (diversified) cities. The higher value of communication in diversified cities seems to be the result of the more crucial role of learning for firms in these cities. Specialised and diversified cities have different comparative advantages. With their location choice, firms exploit these local comparative advantages. For workers, our results suggest that social and communication skills are more valued in diversified than in specialised cities. In terms of urban policy implications, our results indicate that there is no one-policy-fits-all urban development policy as the comparative advantages vary across city types.

\section{References}

Acemoglu, D. and Autor, D. 2011. 'Skills, Tasks and Technologies: Implications for Employment and Earnings'. In Handbook for Labour Economics Volume 4, Part B (Amsterdam: Elsevier) pp. 1043-1171.

Autor, D. and Dorn, D. 2010. 'The Growth of Low-Skill Service Jobs and the Polarization of the U.S. Labor Market'. MIT Working Paper.

Autor, D, Levy, F. and Murnane, R. 2003. 'The Skill Content of Recent Technological Change: An Empirical Exploration'. Quarterly Journal of Economics 118 (4), 12791334.

Bacolod, M., Blum, B. and Strange, W. 2009. 'Skills in the City'. Journal of Urban Economics 65 (2), 136-153.

Borghans, L., Ter Weel, B. and Weinberg, B. 2006. 'People People: Social Capital and the Labor-Market Outcomes of Underrepresented Groups'. NBER Working Paper No. 11985.

Bresnahan, T. 1999. 'Computerisation and Wage Dispersion: An Analytical Reinterpretation'. Economic Journal 109 (456), 390-415. 
Charlot, S. and Duranton, G. 2004. 'Communication externalities in cities'. Journal of Urban Economics 56 (3), 581-613.

Ciccone, A. and Hall, R. 1996. 'Productivity and the Density of Economic Activity'. American Economic Review 86(1), 54-70.

Combes, P., Duranton, G. and Gobillon, L. 2008. 'Spatial Wage Disparities: Sorting Matters!'. Journal of Urban Economics 63(2), 723-742.

Combes, P., Duranton, G. and Gobillon, L. 2009. The Economics of Agglomeration. Chicago and London: University of Chicago Press. chapter Estimating Agglomeration Economics with History, pp. 15-65.

Desmet, K. and Rossi-Hansberg, E. 2009. 'Spatial Growth and Industrial Age'. Journal of Economic Theory 144 (6), 2477-2502.

Duranton, G. and Puga, D. 2000. 'Diversity and Specialisation in Cities: Why, Where and When Does it Matter?'. Urban Studies 37 (3), 533-555.

Duranton, G. and Puga, D. 2001. 'Nursery Cities: Urban diversity, process innovation, and the life cycle of products'. American Economic Review 91 (5), 1454-1477.

Ellison, G. and Glaeser, E. 1999. 'The Geographic Concentration of Industry: Does Natural Advantage Explain Agglomeration?'. American Economic Review 89 (2), 311316.

Feldman, M.P. and Audretsch, D.B. 1999. 'Innovation in cities: Science-based diversity, specialization and localized competition'. European Economic Review 42, no.2, 409-429.

Florida, R., Mellander, C., Stolarick, K. and Ross, A. 2012. 'Cities, Skills and Wages'. Journal of Economic Geography 12 (2), 355-377.

Gaspar, J. and Glaeser, E. 1998. 'Information Technology and the Future of Cities'. Journal of Urban Economics 43 (1), 136-156.

Glaeser, E., Kolko, J. and Saiz, A. 2001. 'Consumer City'. Journal of Economic Geography 1 (1), 27-50.

Glaeser, E. and Maré, D. 2001. 'Cities and Skills'. Journal of Labor Economics 19 (2), 316342.

Glaeser, E. and Ponzetto, A. 2007. 'Did the Death of Distance Hurt Detroit and Help New York?'. NBER Working Paper No. 13710.

Glaeser, E., Schienkman, J. and Shleifer, A. 1995. 'Economic Growth in a Cross-Section of Cities'. Journal of Monetary Economics 36(1), 117-143.

Glaeser, E.L. and Gottlieb, J.D. 2009. 'The Wealth of Cities: Agglomeration Economies and Spatial Equilibrium in the United States'. Journal of Economic Literature 47, No.

4, 983-1028. 
Harrison, B., Kelley, M. and Gant, J. 1996. 'Specialization versus Diversity in Local Economies: The Implications for Innovative Private-Secotr Behavior'. Cityscape: A Journal of Political Development and Research 54, 201-242.

Ioannides, Y.M., Overman, H.G., E., Rossi-Hansberg and Schmidheiny, K. 2008. 'The effect of information and communication technologies on urban structure'. Economic Policy 23, no.54, 201-242.

Jacobs, J. 1969. The Economy of Cities. Pinghuin Books.

Jaffe, A., Trajtenberg, M. and Henderson, R. 1993. 'Geographic Localization of Knowledge Spillovers as Evidence by Patent Citations'. Quarterly Journal of Economics 108(3), 577598.

Kelley, M. and Helper, S. 1999. 'Firm Size and Capabilities, Regional Agglomeration, and the Adoption of New Technology'. Economics of Innovation and New Technology 8 (2), 79-103.

Lewis, E. 2011. 'Immigrant-Native Substitutability: The Role of Language Ability'. NBER Working Paper No: 17609.

Lucas, R.E. Jr. 1988. 'On the Mechanics of Economic Development'. Journal of Monetary Economics 22(1), 3-42.

Moulton, B. 1990. 'An Illustration of a Pitfall in Estimating the Effects of Aggregate Variables on Micro-units'. The Review of Economics and Statistics 72, No. 2, 334-338.

Mouw, T. and Kallenberg, A.L. 2010. 'Occupations and the Structure of Wage Inequality in the United States, 1980 to 2000s'. American Sociological Review 75(3), 402-431.

Rauch, J. 1993. 'Does History Matter Only When It Matters Little?'. Quarterly Journal of Economics 108(3), 843-867.

Storper, M. and Venables, A. 2004. 'Buzz: face-to-face contact and the urban economy'. Journal of Economic Geography 4 (4), 351-370. 


\section{DATA APPENDIX}

\section{A Data source}

\section{A.1. Current Population Survey | May Outgoing Rotation Group}

The May Outgoing Rotation Group (MORG) of the Current Population Survey is used as these files include detailed information about earnings and working hours. The files contain individual information about employment and other labour-market variables. For instance it contains information on occupation, industry, hours worked, earnings, education, unionisation and a wide variety of demographic variables. Detailed information about this dataset can be found at http://www.census.gov/cps/.

\section{A.2 ONET Skill Survey}

Detailed information about the performance of communication job tasks and other job activities is gathered from the ONET Skill Database (www.onetcenter.org). The 3.0 version is used for this paper. For each occupation this database provides information about the importance of workers abilities, interest, knowledge, skills, work activities and work context. Work activities are defined as 'General types of job behaviours occurring on multiple jobs.', work context as 'Physical and social factors that influence the nature of work'. Work activities are scaled from 0 to 6 and work context from 0 to 100 . To obtain similar scores, we standardized all work activities and context with mean 0 and standard deviation 1.

\section{A.3 Local Area Unemployment Statistics}

To compute employment figures for Metropolitan Statistical Areas (MSAs), we gather county employment figures from the Local Area Unemployment Statistics of the Bureau of Labor Statistics (BLS). Counties are merged into MSAs following the 1990 definition of the Census. Details on the construction of the city classifications are given below. 


\section{B. Classifications}

\section{B.1 Cities}

Cities are classified by Metropolitan Statistical Areas in the Current Population Survey. MSAs are defined by the nature of their economic activity. The MSA classifications are updated over time following the scope of regional economic activity. We add several city characteristics to the MSA information provided by the CPS which leads to definition issues. To define time consistent MSA definitions we use the 1990 definition of the Census which combines counties into MSAs. As county borders do not change over time, our MSA classification represents cities, which do not change in geographical size over time. Thus, additional city information covers a time consistent MSA definition. This city classification leads to a sample of $168 \mathrm{MSAs}$, which borders are stable over time.

\section{B.2 Industries}

Our industry classification includes 142 three-digit and 11 two-digit industries. The distribution of industries across cities equals the County Business Patterns distribution.

\section{B.3 Occupations}

The occupational classification includes 326 three-digit and 10 two-digit occupations and follows the classification of Autor and Dorn (2010). To match information from the ONET Skill Survey to the Current Population Survey, the occupation classification from the ONET is matched to these 326 occupations. The occupation classification of ONET varies over time, the classification of ONET version 3.0 provides the most accurate match to the CPS and it used in this paper. 


\section{Variables}

Table C.1 Variables

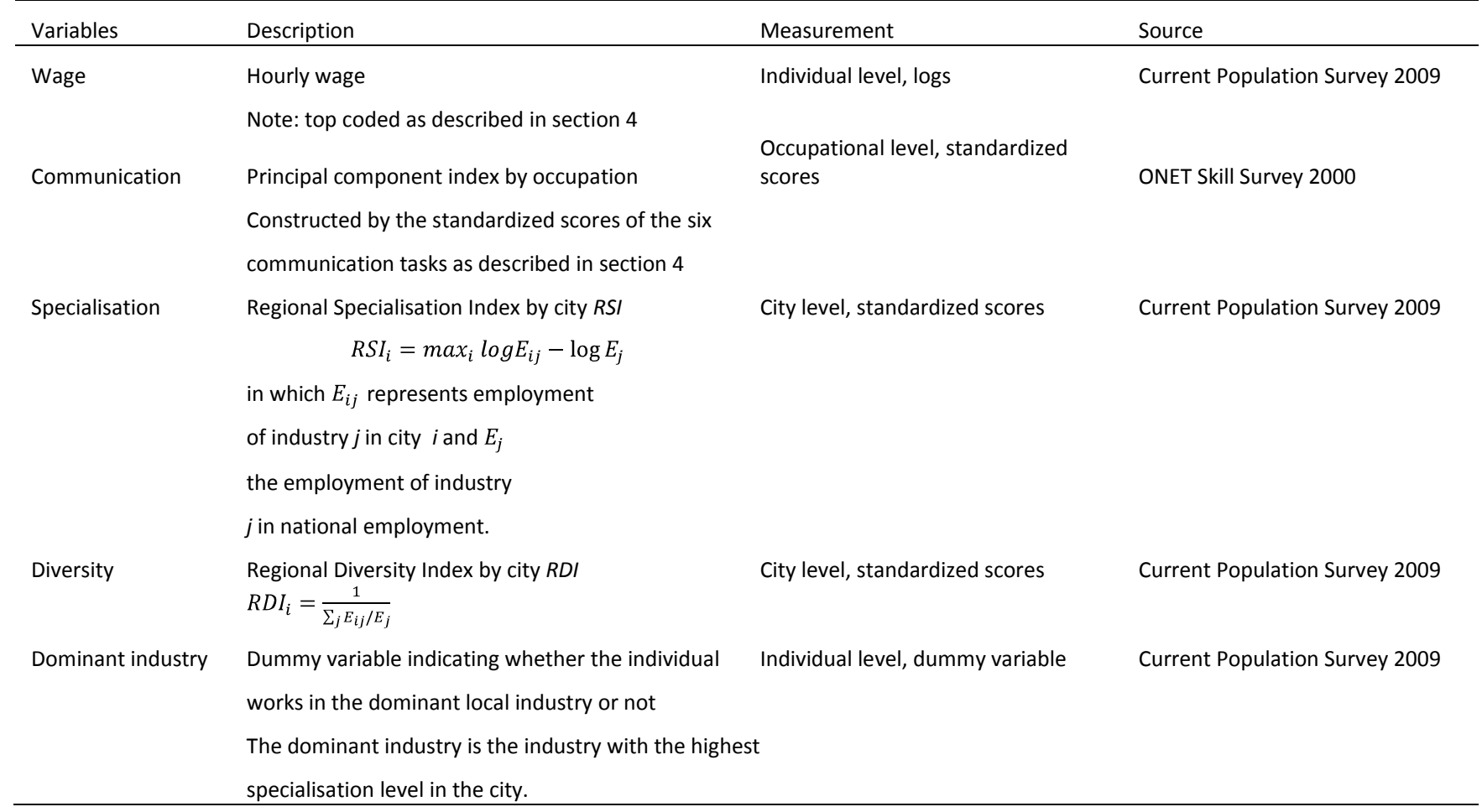

Table C.2 Control Variables

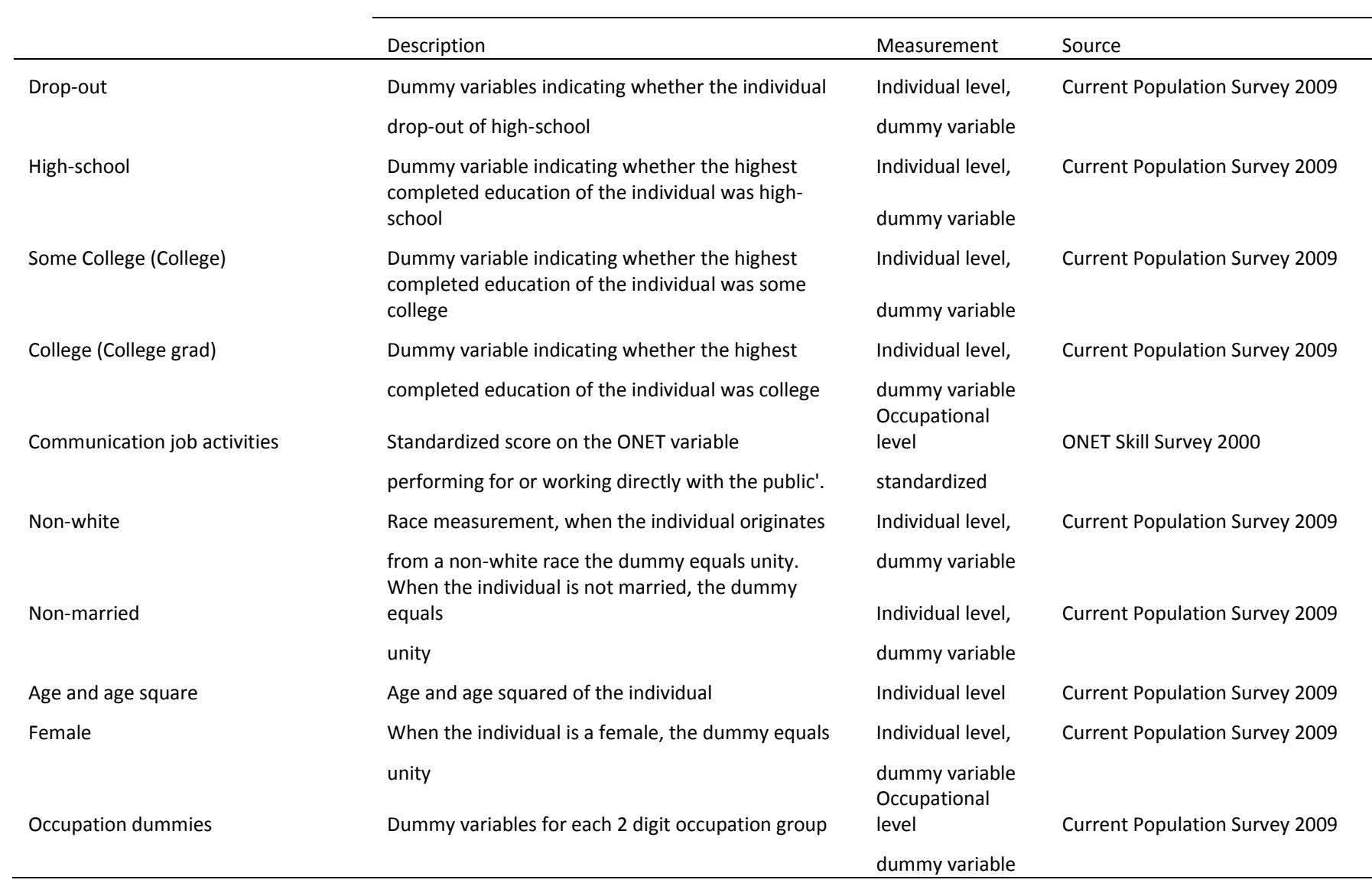


Table C.3. Additional / robustness variables

\begin{tabular}{|c|c|c|c|}
\hline & \\
\hline & Description & Measurement & Source \\
\hline Size & Employment by MSA & $\begin{array}{l}\text { City level, } \\
\text { standardized logs }\end{array}$ & $\begin{array}{l}\text { Local Unemployment Figures } \\
2009\end{array}$ \\
\hline \multirow[t]{5}{*}{ Language-skill proxy } & $\begin{array}{l}\text { Average score on the following category: } \\
\text { Who originates from a non-English speaking } \\
\text { country? }\end{array}$ & $\begin{array}{l}\text { Occupational level, } \\
\text { standardized shares }\end{array}$ & Current Population Survey 2009 \\
\hline & Category 1: the worker him/herself & & \\
\hline & Category 2: both parents of the worker & & \\
\hline & Category 3: one of the parents of the worker & & \\
\hline & Category 4: nobody & & \\
\hline Population 1930 & County population in 1930 , summed by MSA & City level, & $\begin{array}{l}\text { Census Historical Population } \\
\text { Figures }\end{array}$ \\
\hline Relative communication & $\begin{array}{l}\text { Share of communication job tasks within the total } \\
\text { score of job tasks by occupation }\end{array}$ & standardized logs & ONET Skill Survey 2000 \\
\hline Non-routine interactive & $\begin{array}{l}\text { Occupational score on the non-routine interactive } \\
\text { job tasks as defined in Acemoglu and Autor (2011) }\end{array}$ & $\begin{array}{l}\text { Occupational level, } \\
\text { score }\end{array}$ & ONET Skill Survey 2000 \\
\hline Rent & Standardized average rent by MSA in 2000 & $\begin{array}{l}\text { City level, } \\
\text { standardized averages }\end{array}$ & Census 2000 \\
\hline
\end{tabular}




\section{Table C. 4 Correlation matrix}

\begin{tabular}{|c|c|c|c|c|c|c|c|c|c|c|c|c|c|c|c|c|c|c|c|c|}
\hline & (1) & (2) & (3) & (4) & (5) & (6) & (7) & (8) & (9) & (10) & (11) & (12) & (13) & (14) & (15) & (16) & (17) & (18) & (19) & (20) \\
\hline (1) wage & 1.00 & & & & & & & & & & & & & & & & & & & \\
\hline (2) communication & $\begin{array}{l}0.40 \\
(0.00)\end{array}$ & 1.00 & & & & & & & & & & & & & & & & & & \\
\hline (3) RSI & $\begin{array}{l}-0.11 \\
(0.00)\end{array}$ & $\begin{array}{l}-0.04 \\
(0.00)\end{array}$ & 1.00 & & & & & & & & & & & & & & & & & \\
\hline (4) RDI & $\begin{array}{l}0.03 \\
(0.00)\end{array}$ & $\begin{array}{c}0.01 \\
(0.00)\end{array}$ & $\begin{array}{l}-0.45 \\
(0.00)\end{array}$ & 1.00 & & & & & & & & & & & & & & & & \\
\hline (5) Dom. ind & $\begin{array}{r}0.04 \\
(0.00)\end{array}$ & $\begin{array}{l}-0.03 \\
(0.00)\end{array}$ & $\begin{array}{c}0.00 \\
(0.53)\end{array}$ & $\begin{array}{l}-0.09 \\
(0.00)\end{array}$ & 1.00 & & & & & & & & & & & & & & & \\
\hline (6) Drop-out & $\begin{array}{l}-0.26 \\
(0.00)\end{array}$ & $\begin{array}{l}-0.30 \\
(0.00)\end{array}$ & $\begin{array}{l}-0.00 \\
(0.68)\end{array}$ & $\begin{array}{r}-0.00 \\
(0.52)\end{array}$ & $\begin{array}{c}0.01 \\
(0.00)\end{array}$ & 1.00 & & & & & & & & & & & & & & \\
\hline (7) High-school & $\begin{array}{l}-0.22 \\
(0.00)\end{array}$ & $\begin{array}{l}-0.27 \\
(0.00)\end{array}$ & $\begin{array}{l}0.04 \\
(0.00)\end{array}$ & $\begin{array}{l}-0.01 \\
(0.00)\end{array}$ & $\begin{array}{l}-0.01 \\
(0.02)\end{array}$ & $\begin{array}{l}-0.17 \\
(0.00)\end{array}$ & 1.00 & & & & & & & & & & & & & \\
\hline (8) College & $\begin{array}{c}-0.12 \\
(0.00)\end{array}$ & $\begin{array}{l}-0.01 \\
(0.00)\end{array}$ & $\begin{array}{c}0.06 \\
(0.00)\end{array}$ & $\begin{array}{l}-0.01 \\
(0.00)\end{array}$ & $\begin{array}{c}-0.02 \\
(0.00)\end{array}$ & $\begin{array}{r}-0.19 \\
(0.00)\end{array}$ & $\begin{array}{l}-0.38 \\
(0.00)\end{array}$ & 1.00 & & & & & & & & & & & & \\
\hline (9) College grad & $\begin{array}{l}0.46 \\
(0.00)\end{array}$ & $\begin{array}{l}0.42 \\
(0.00)\end{array}$ & $\begin{array}{l}-0.09 \\
(0.00)\end{array}$ & $\begin{array}{l}0.02 \\
(0.00)\end{array}$ & $\begin{array}{l}0.01 \\
(0.00)\end{array}$ & $\begin{array}{l}-0.22 \\
(0.00)\end{array}$ & $\begin{array}{l}-0.46 \\
(0.00)\end{array}$ & $\begin{array}{l}-0.49 \\
(0.00)\end{array}$ & 1.00 & & & & & & & & & & & \\
\hline $\begin{array}{l}\text { (10) Com. job } \\
\text { activities }\end{array}$ & $\begin{array}{l}-0.09 \\
(0.00)\end{array}$ & $\begin{array}{l}0.32 \\
(0.00)\end{array}$ & $\begin{array}{l}-0.01 \\
(0.07)\end{array}$ & $\begin{array}{c}0.01 \\
(0.00)\end{array}$ & $\begin{array}{l}-0.04 \\
(0.00)\end{array}$ & $\begin{array}{l}-0.08 \\
(0.00)\end{array}$ & $\begin{array}{l}-0.08 \\
(0.00)\end{array}$ & $\begin{array}{c}0.05 \\
(0.00)\end{array}$ & $\begin{array}{c}0.08 \\
(0.00)\end{array}$ & 1.00 & & & & & & & & & & \\
\hline (11) Non-white & $\begin{array}{l}-0.07 \\
(0.00)\end{array}$ & $\begin{array}{l}-0.04 \\
(0.00)\end{array}$ & $\begin{array}{l}-0.13 \\
(0.00)\end{array}$ & $\begin{array}{l}-0.01 \\
(0.00)\end{array}$ & $\begin{array}{c}0.00 \\
(0.41)\end{array}$ & $\begin{array}{l}-0.02 \\
(0.00)\end{array}$ & $\begin{array}{c}0.02 \\
(0.00)\end{array}$ & $\begin{array}{c}0.01 \\
(0.00)\end{array}$ & $\begin{array}{l}-0.02 \\
(0.00)\end{array}$ & $\begin{array}{c}0.02 \\
(0.00)\end{array}$ & 1.00 & & & & & & & & & \\
\hline (12) Non-married & $\begin{array}{l}-0.24 \\
(0.00)\end{array}$ & $\begin{array}{l}-0.11 \\
(0.00)\end{array}$ & $\begin{array}{l}-0.02 \\
(0.00)\end{array}$ & $\begin{array}{l}-0.01 \\
(0.05)\end{array}$ & $\begin{array}{c}-0.01 \\
(0.02)\end{array}$ & $\begin{array}{r}0.05 \\
(0.00)\end{array}$ & $\begin{array}{c}0.03 \\
(0.00)\end{array}$ & $\begin{array}{r}0.06 \\
(0.00)\end{array}$ & $\begin{array}{r}-0.12 \\
(0.00)\end{array}$ & $\begin{array}{r}0.07 \\
(0.00)\end{array}$ & $\begin{array}{r}0.08 \\
(0.00)\end{array}$ & 1.00 & & & & & & & & \\
\hline (13) Age & $\begin{array}{c}0.29 \\
(0.00)\end{array}$ & $\begin{array}{c}0.10 \\
(0.00)\end{array}$ & $\begin{array}{c}0.00 \\
(0.17)\end{array}$ & $\begin{array}{c}0.00 \\
(0.20)\end{array}$ & $\begin{array}{c}0.02 \\
(0.00)\end{array}$ & $\begin{array}{c}-0.09 \\
(0.00)\end{array}$ & $\begin{array}{c}0.01 \\
(0.00)\end{array}$ & $\begin{array}{l}-0.05 \\
(0.00)\end{array}$ & $\begin{array}{c}0.09 \\
(0.00)\end{array}$ & $\begin{array}{l}-0.10 \\
(0.00)\end{array}$ & $\begin{array}{l}-0.02 \\
(0.00)\end{array}$ & $\begin{array}{c}-0.34 \\
(0.00)\end{array}$ & 1.00 & & & & & & & \\
\hline (14) Age square & $\begin{array}{r}0.26 \\
(0.00)\end{array}$ & $\begin{array}{c}0.09 \\
(0.00)\end{array}$ & $\begin{array}{l}0.01 \\
(0.01)\end{array}$ & $\begin{array}{c}0.00 \\
(0.36)\end{array}$ & $\begin{array}{c}0.02 \\
(0.00)\end{array}$ & $\begin{array}{l}-0.08 \\
(0.00)\end{array}$ & $\begin{array}{c}0.02 \\
(0.00)\end{array}$ & $\begin{array}{l}-0.04 \\
(0.00)\end{array}$ & $\begin{array}{c}0.07 \\
(0.00)\end{array}$ & $\begin{array}{l}-0.08 \\
(0.00)\end{array}$ & $\begin{array}{l}-0.03 \\
(0.00)\end{array}$ & $\begin{array}{l}-0.30 \\
(0.00)\end{array}$ & $\begin{array}{l}0.99 \\
(0.00)\end{array}$ & 1.00 & & & & & & \\
\hline
\end{tabular}


Table C. 4 Correlation matrix - continued

\begin{tabular}{|c|c|c|c|c|c|c|c|c|c|c|c|c|c|c|c|c|c|c|c|c|}
\hline & (1) & (2) & (3) & (4) & (5) & (6) & (7) & (8) & (9) & (10) & (11) & (12) & (13) & (14) & (15) & (16) & (17) & (18) & (19) & (20) \\
\hline (15) Female & $\begin{array}{l}-0.16 \\
(0.00)\end{array}$ & $\begin{array}{c}0.13 \\
(0.00)\end{array}$ & $\begin{array}{l}0.00 \\
(0.37)\end{array}$ & $\begin{array}{l}-0.00 \\
(0.78)\end{array}$ & $\begin{array}{l}-0.03 \\
(0.00)\end{array}$ & $\begin{array}{l}-0.05 \\
(0.00)\end{array}$ & $\begin{array}{l}-0.03 \\
(0.00)\end{array}$ & $\begin{array}{l}0.05 \\
(0.00)\end{array}$ & $\begin{array}{c}0.01 \\
(0.03)\end{array}$ & $\begin{array}{c}0.24 \\
(0.00)\end{array}$ & $\begin{array}{l}0.05 \\
(0.00)\end{array}$ & $\begin{array}{l}0.06 \\
(0.00)\end{array}$ & $\begin{array}{c}0.02 \\
(0.00)\end{array}$ & $\begin{array}{c}0.02 \\
(0.00)\end{array}$ & 1.00 & & & & & \\
\hline (16) Size & $\begin{array}{l}0.10 \\
(0.00)\end{array}$ & $\begin{array}{l}0.03 \\
(0.00)\end{array}$ & $\begin{array}{l}-0.66 \\
(0.00)\end{array}$ & $\begin{array}{c}0.57 \\
(0.00)\end{array}$ & $\begin{array}{c}0.01 \\
(0.00)\end{array}$ & $\begin{array}{l}0.03 \\
(0.00)\end{array}$ & $\begin{array}{l}-0.04 \\
(0.00)\end{array}$ & $\begin{array}{l}-0.05 \\
(0.00)\end{array}$ & $\begin{array}{c}0.07 \\
(0.00)\end{array}$ & $\begin{array}{l}-0.00 \\
(0.41)\end{array}$ & $\begin{array}{c}0.07 \\
(0.00)\end{array}$ & $\begin{array}{l}0.02 \\
(0.00)\end{array}$ & $\begin{array}{l}-0.01 \\
(0.01)\end{array}$ & $\begin{array}{l}-0.01 \\
(0.00)\end{array}$ & $\begin{array}{l}-0.01 \\
(0.01)\end{array}$ & 1.00 & & & & \\
\hline $\begin{array}{l}\text { (17) Proxy } \\
\text { communication }\end{array}$ & $\begin{array}{l}0.27 \\
(0.00)\end{array}$ & $\begin{array}{l}0.67 \\
(0.00)\end{array}$ & $\begin{array}{l}-0.01 \\
(0.04)\end{array}$ & $\begin{array}{l}0.00 \\
(0.23)\end{array}$ & $\begin{array}{l}-0.03 \\
(0.00)\end{array}$ & $\begin{array}{l}-0.31 \\
(0.00)\end{array}$ & $\begin{array}{l}-0.16 \\
(0.00)\end{array}$ & $\begin{array}{l}0.06 \\
(0.00)\end{array}$ & $\begin{array}{c}0.26 \\
(0.00)\end{array}$ & $\begin{array}{l}0.27 \\
(0.00)\end{array}$ & $\begin{array}{l}-0.06 \\
(0.00)\end{array}$ & $\begin{array}{l}-0.07 \\
(0.00)\end{array}$ & $\begin{array}{l}0.08 \\
(0.00)\end{array}$ & $\begin{array}{l}0.07 \\
(0.00)\end{array}$ & $\begin{array}{c}0.11 \\
(0.00)\end{array}$ & $\begin{array}{l}-0.00 \\
(0.74)\end{array}$ & 1.00 & & & \\
\hline $\begin{array}{l}\text { (18) Population } \\
1930\end{array}$ & $\begin{array}{r}0.06 \\
(0.00)\end{array}$ & $\begin{array}{c}0.02 \\
(0.00)\end{array}$ & $\begin{array}{l}-0.51 \\
(0.00)\end{array}$ & $\begin{array}{c}0.61 \\
(0.00)\end{array}$ & $\begin{array}{l}-0.05 \\
(0.00)\end{array}$ & $\begin{array}{c}0.01 \\
(0.01)\end{array}$ & $\begin{array}{l}-0.02 \\
(0.00)\end{array}$ & $\begin{array}{l}-0.04 \\
(0.00)\end{array}$ & $\begin{array}{l}0.05 \\
(0.00)\end{array}$ & $\begin{array}{l}-0.01 \\
(0.00)\end{array}$ & $\begin{array}{l}0.03 \\
(0.00)\end{array}$ & $\begin{array}{c}0.00 \\
(0.33)\end{array}$ & $\begin{array}{l}-0.00 \\
(0.82)\end{array}$ & $\begin{array}{l}-0.00 \\
(0.47)\end{array}$ & $\begin{array}{l}-0.00 \\
(0.64)\end{array}$ & $\begin{array}{l}0.72 \\
(0.00)\end{array}$ & $\begin{array}{l}0.00 \\
(0.69)\end{array}$ & 1.00 & & \\
\hline $\begin{array}{l}\text { (19) Communication } \\
\text { share }\end{array}$ & $\begin{array}{c}0.11 \\
(0.00)\end{array}$ & $\begin{array}{l}0.52 \\
(0.00)\end{array}$ & $\begin{array}{l}-0.03 \\
(0.00)\end{array}$ & $\begin{array}{c}0.01 \\
(0.06)\end{array}$ & $\begin{array}{l}-0.01 \\
(0.00)\end{array}$ & $\begin{array}{l}-0.13 \\
(0.00)\end{array}$ & $\begin{array}{l}-0.07 \\
(0.00)\end{array}$ & $\begin{array}{l}-0.01 \\
(0.00)\end{array}$ & $\begin{array}{c}0.15 \\
(0.00)\end{array}$ & $\begin{array}{l}0.34 \\
(0.00)\end{array}$ & $\begin{array}{l}-0.06 \\
(0.00)\end{array}$ & $\begin{array}{l}-0.02 \\
(0.00)\end{array}$ & $\begin{array}{c}0.03 \\
(0.00)\end{array}$ & $\begin{array}{l}0.03 \\
(0.00)\end{array}$ & $\begin{array}{l}0.04 \\
(0.00)\end{array}$ & $\begin{array}{l}0.03 \\
(0.00)\end{array}$ & $\begin{array}{c}0.45 \\
(0.00)\end{array}$ & $\begin{array}{l}0.01 \\
(0.03)\end{array}$ & 1.00 & \\
\hline (20) RTI & $\begin{array}{l}0.35 \\
(0.00)\end{array}$ & $\begin{array}{l}0.76 \\
(0.00)\end{array}$ & $\begin{array}{l}-0.02 \\
(0.00)\end{array}$ & $\begin{array}{c}0.00 \\
(0.16)\end{array}$ & $\begin{array}{l}-0.01 \\
(0.00)\end{array}$ & $\begin{array}{l}-0.19 \\
(0.00)\end{array}$ & $\begin{array}{l}-0.22 \\
(0.00)\end{array}$ & $\begin{array}{l}-0.07 \\
(0.00)\end{array}$ & $\begin{array}{l}0.38 \\
(0.00)\end{array}$ & $\begin{array}{l}0.13 \\
(0.00)\end{array}$ & $\begin{array}{l}-0.05 \\
(0.00)\end{array}$ & $\begin{array}{l}-0.12 \\
(0.00)\end{array}$ & $\begin{array}{c}0.11 \\
(0.00)\end{array}$ & $\begin{array}{c}0.09 \\
(0.00)\end{array}$ & $\begin{array}{l}0.04 \\
(0.00)\end{array}$ & $\begin{array}{c}0.02 \\
(0.00)\end{array}$ & $\begin{array}{c}0.42 \\
(0.00)\end{array}$ & $\begin{array}{c}0.01 \\
(0.00)\end{array}$ & $\begin{array}{c}0.29 \\
(0.00)\end{array}$ & 1.00 \\
\hline (21) Rent & $\begin{array}{l}0.12 \\
(0.00)\end{array}$ & $\begin{array}{c}0.02 \\
(0.00)\end{array}$ & $\begin{array}{l}-0.36 \\
(0.00)\end{array}$ & $\begin{array}{c}0.13 \\
(0.00)\end{array}$ & $\begin{array}{l}0.00 \\
(0.24)\end{array}$ & $\begin{array}{c}0.00 \\
(0.75)\end{array}$ & $\begin{array}{l}-0.06 \\
(0.00)\end{array}$ & $\begin{array}{l}-0.03 \\
(0.00)\end{array}$ & $\begin{array}{l}0.08 \\
(0.00)\end{array}$ & $\begin{array}{l}-0.00 \\
(0.84)\end{array}$ & $\begin{array}{c}0.15 \\
(0.00)\end{array}$ & $\begin{array}{c}0.02 \\
(0.00)\end{array}$ & $\begin{array}{l}-0.00 \\
(0.86)\end{array}$ & $\begin{array}{l}-0.00 \\
(0.30)\end{array}$ & $\begin{array}{l}-0.01 \\
(0.00)\end{array}$ & $\begin{array}{l}0.27 \\
(0.00)\end{array}$ & $\begin{array}{l}-0.01 \\
(0.01)\end{array}$ & $\begin{array}{l}0.14 \\
(0.00)\end{array}$ & $\begin{array}{c}0.02 \\
(0.00)\end{array}$ & $\begin{array}{l}0.01 \\
(0.01)\end{array}$ \\
\hline
\end{tabular}

Note: P-values in parentheses. See Appendix C for a detailed description of the variables, measurement and data sources. 
Table C.5: Correlations among communication tasks

\begin{tabular}{lcccccc}
\hline & (1) & (2) & (3) & (4) & (5) & (6) \\
\hline (1) Relations & 1.000 & & & & & \\
(2) External communication & 0.800 & 1.000 & & & & \\
(3) Internal communication & 0.658 & 0.603 & 1.000 & & & \\
(4) Face-to-face & 0.479 & 0.447 & 0.500 & 1.000 & & \\
(5) Teamwork & 0.420 & 0.332 & 0.512 & 0.544 & 1.000 & \\
(6) Contact & 0.579 & 0.522 & 0.308 & 0.472 & 0.535 & 1.000 \\
\hline
\end{tabular}

Table C.6: PCA results for communication tasks

\begin{tabular}{ll}
\hline & $\begin{array}{l}\text { Communication-index } \\
\text { loadings for first principal } \\
\text { component }\end{array}$ \\
\hline Relations & 0.456 \\
External communication & 0.429 \\
Internal communication & 0.416 \\
Face-to-face & 0.386 \\
Teamwork & 0.371 \\
Contact & 0.386 \\
\hline Explained variance & 0.599 \\
\hline
\end{tabular}




\section{Additional figures}

Figure D1: Native inhabitants in specialised and diversified cities
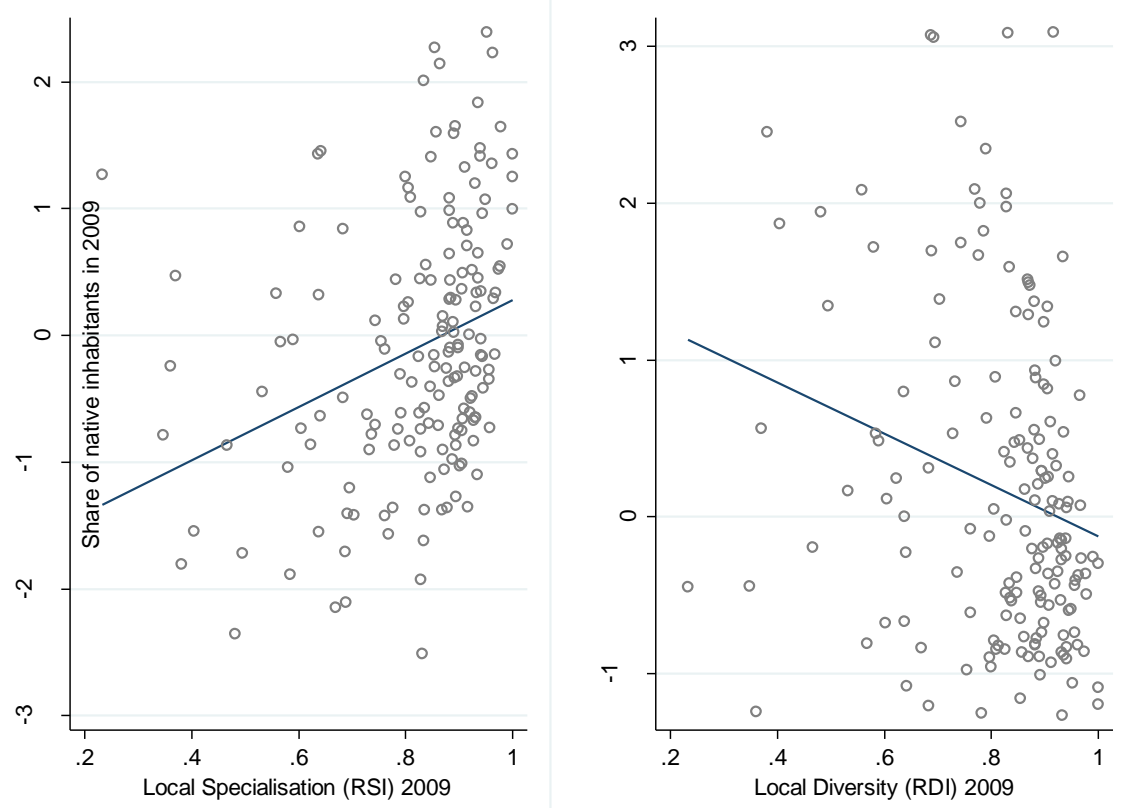

Note: source Current Population Survey 2009. City level data, $n=168$. The correlations are respectively $0.30(0.00)$ and $-0.23(0.00)$ and significant at the $1 \%$ level. $R S I$ and $R D I$ are measured as described in Section 3. Natives are defined as workers born in the US and are measured as share of employment.

\section{Figure D2: Communication and native inhabitants}

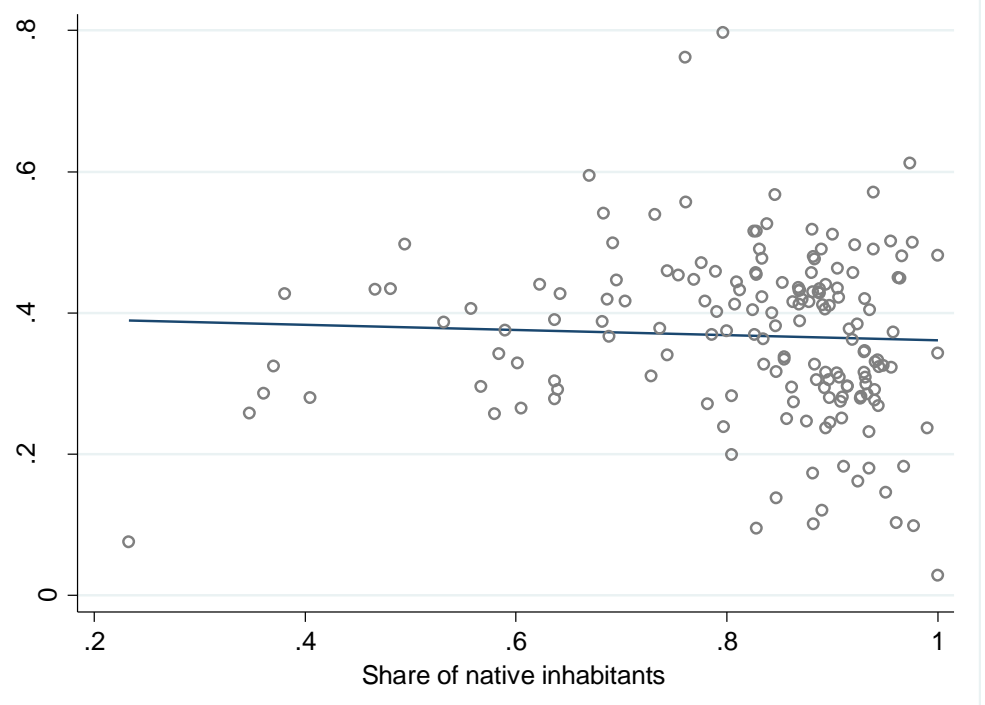

Note: source Current Population Survey 2009. City level data, $n=168$. The correlation is $-0.08(0.34)$ and not significant. Communication is measured as the average score on the Communication-Index as defined in Section 4. Natives are defined as workers born in the US and are measured as share of employment. 

Publisher:

CPB Netherlands Bureau for Economic Policy Analysis

P.O. Box $80510 \mid 2508$ GM The Hague

$\mathrm{T}(070) 3383380$

March 2013 | ISBN 978-90-5833-590-6 